\title{
Advances in Lewis Acid Controlled Carbon-Carbon Bond Forming Reactions Enable a Concise and Convergent Total Synthesis of Bullatacin
}

Hongda Zhao, Jeffrey S. T. Gorman and Brian L. Pagenkopf*

The Department of Chemistry, The University of Western Ontario, London, ON N6A $5 B 7$ and The Department of Chemistry, University of Texas, Austin, $T X 78712$

bpagenko@uwo.ca 


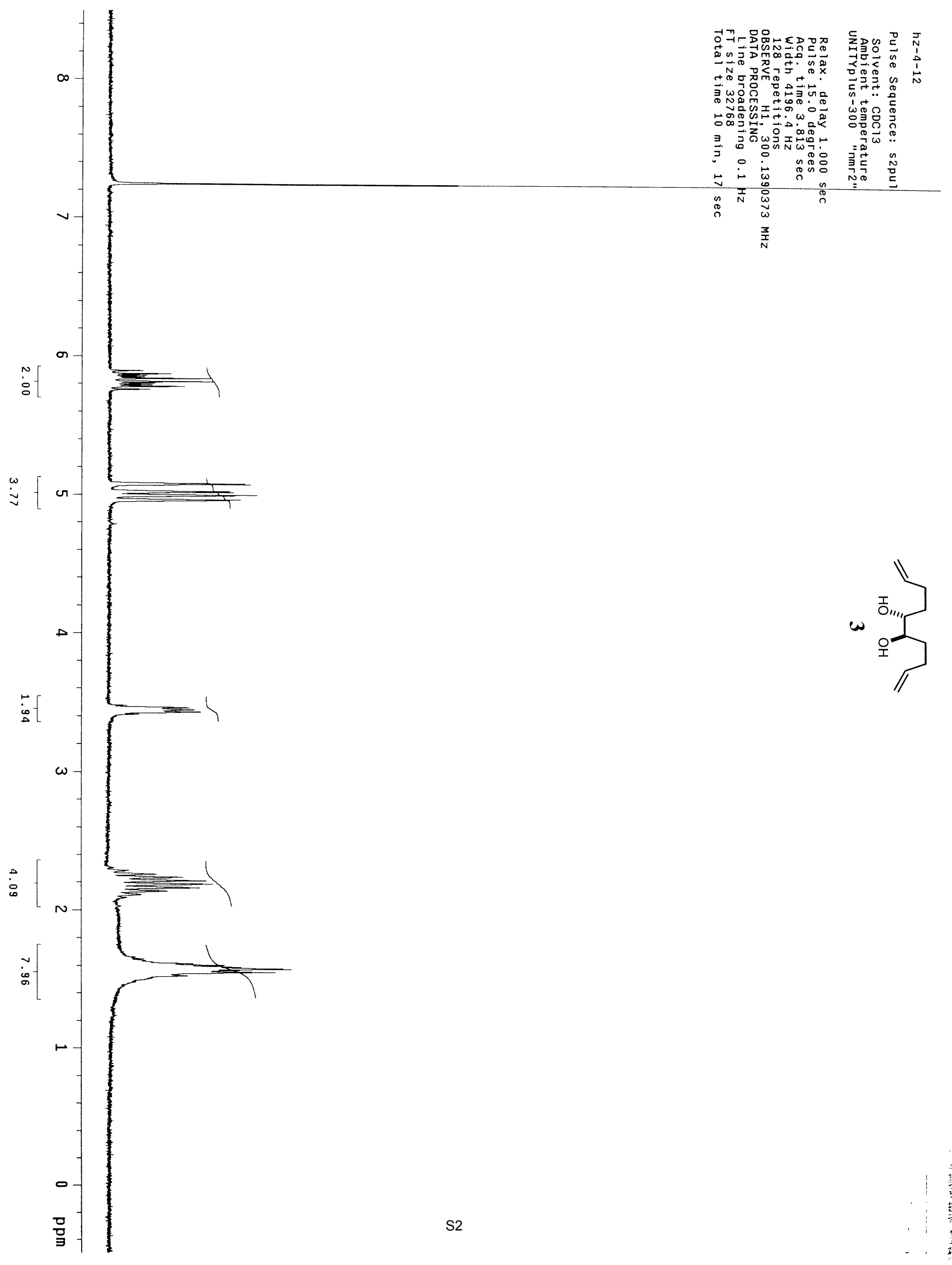




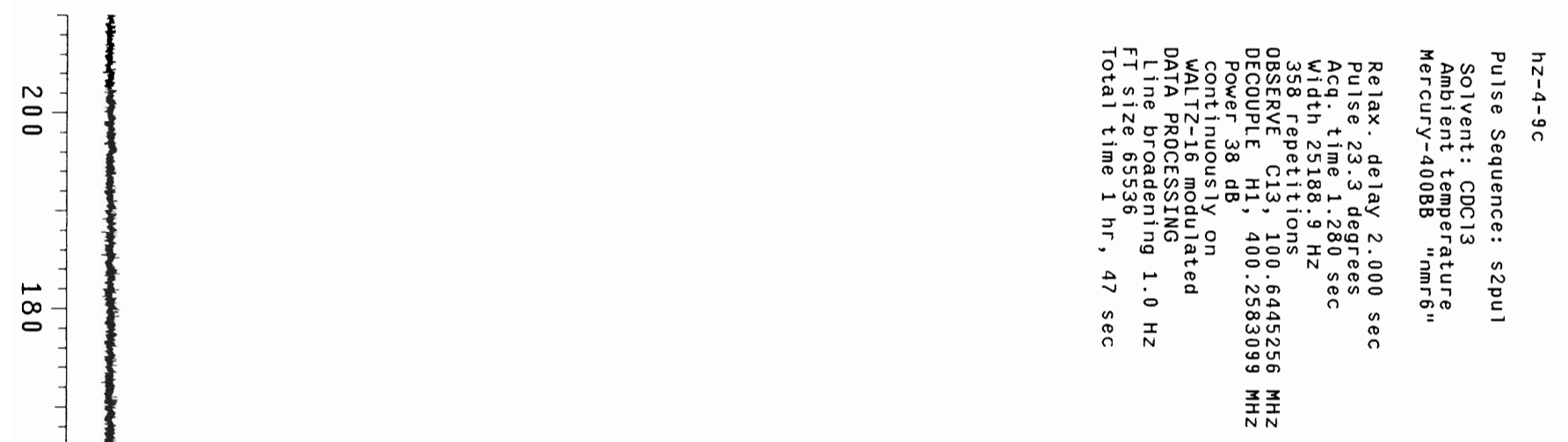

138.257

115.038

$\infty$

ஸ

0

吕-

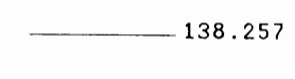

เே
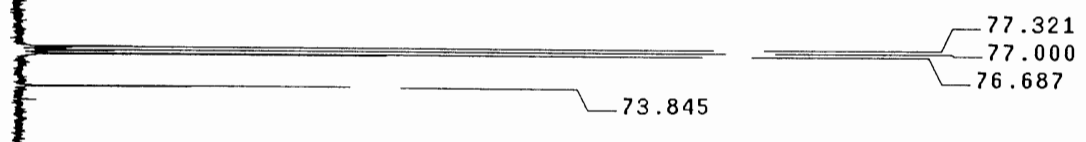

9

-

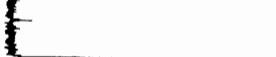

$-29.896$

N

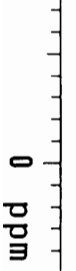

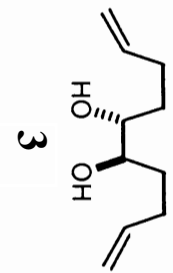




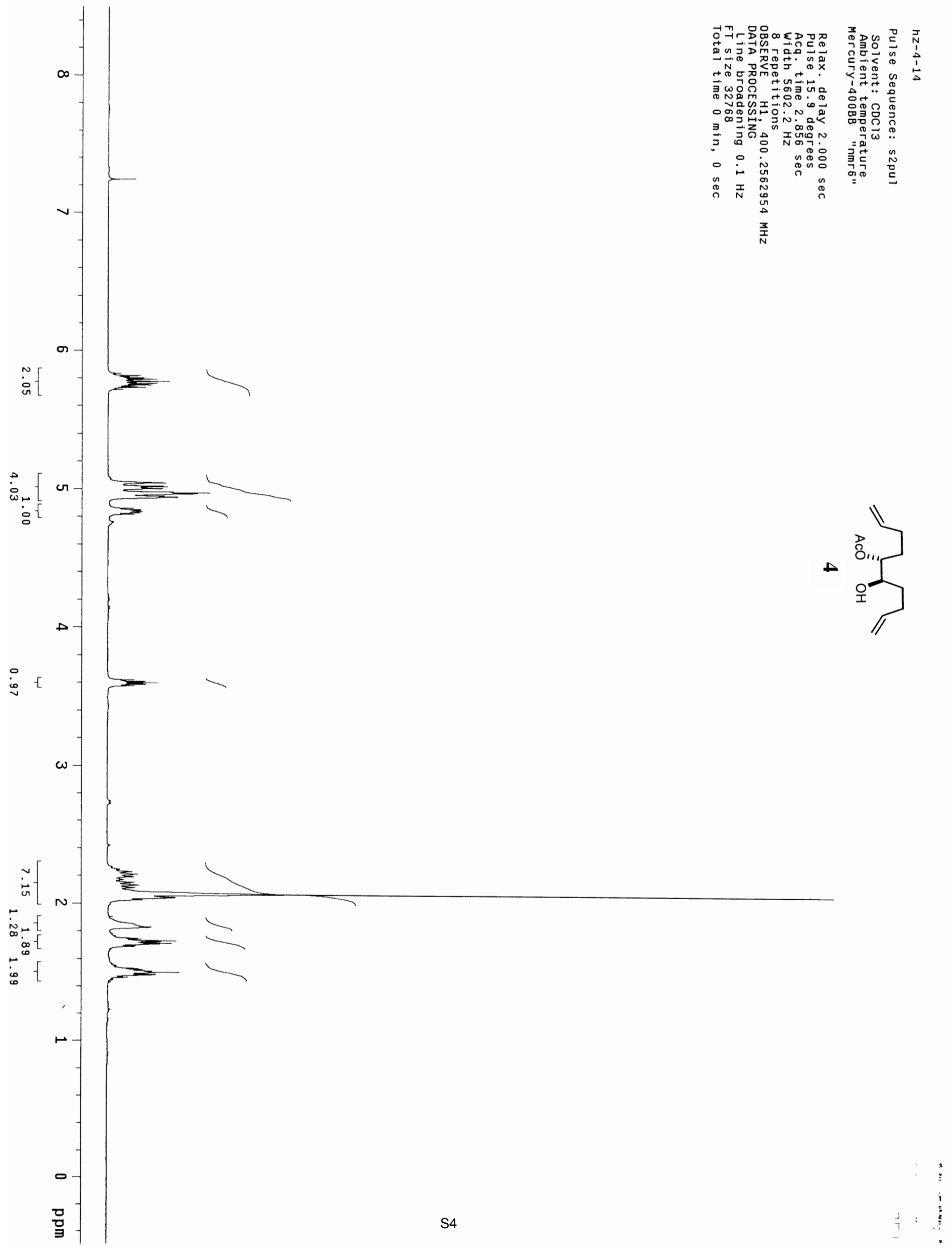



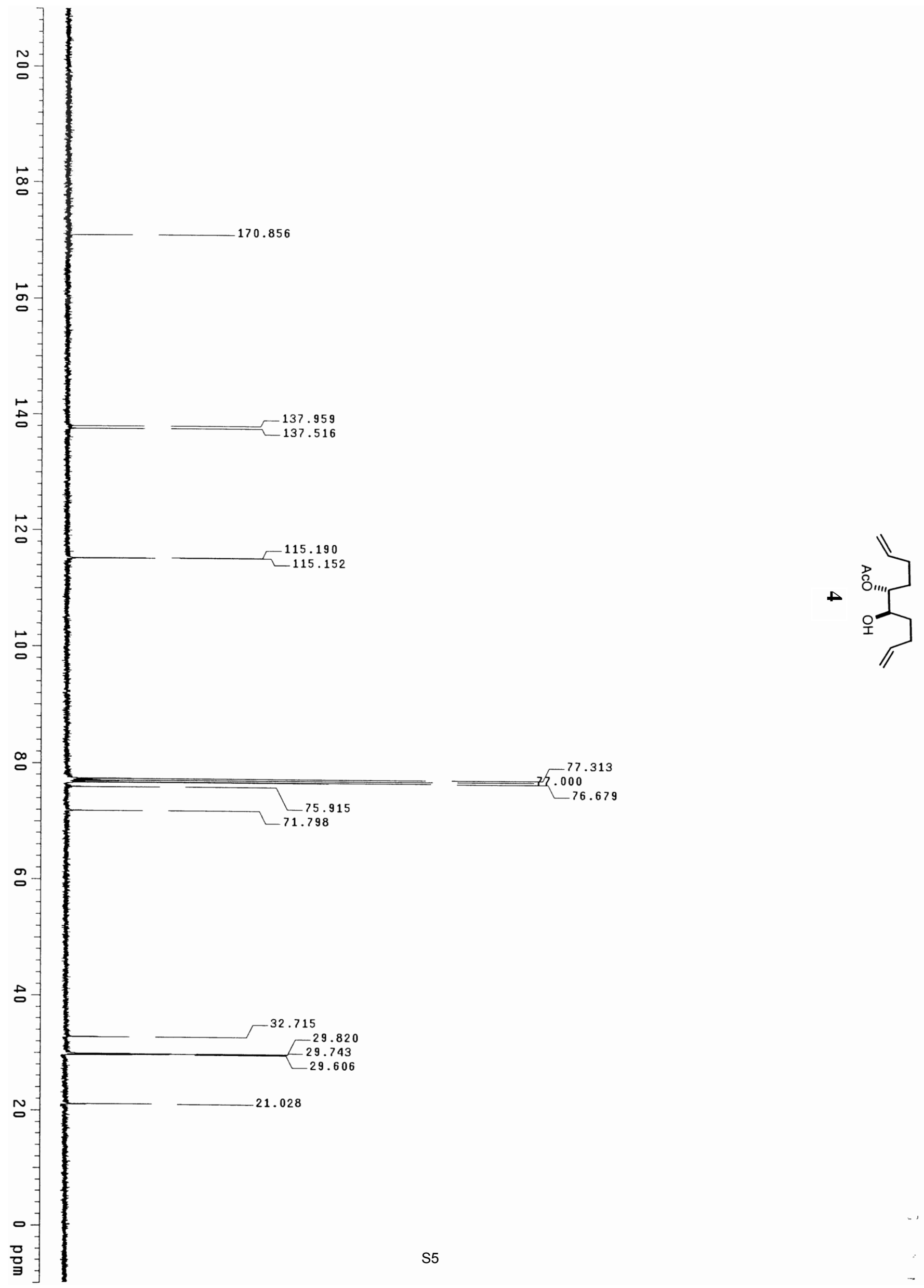


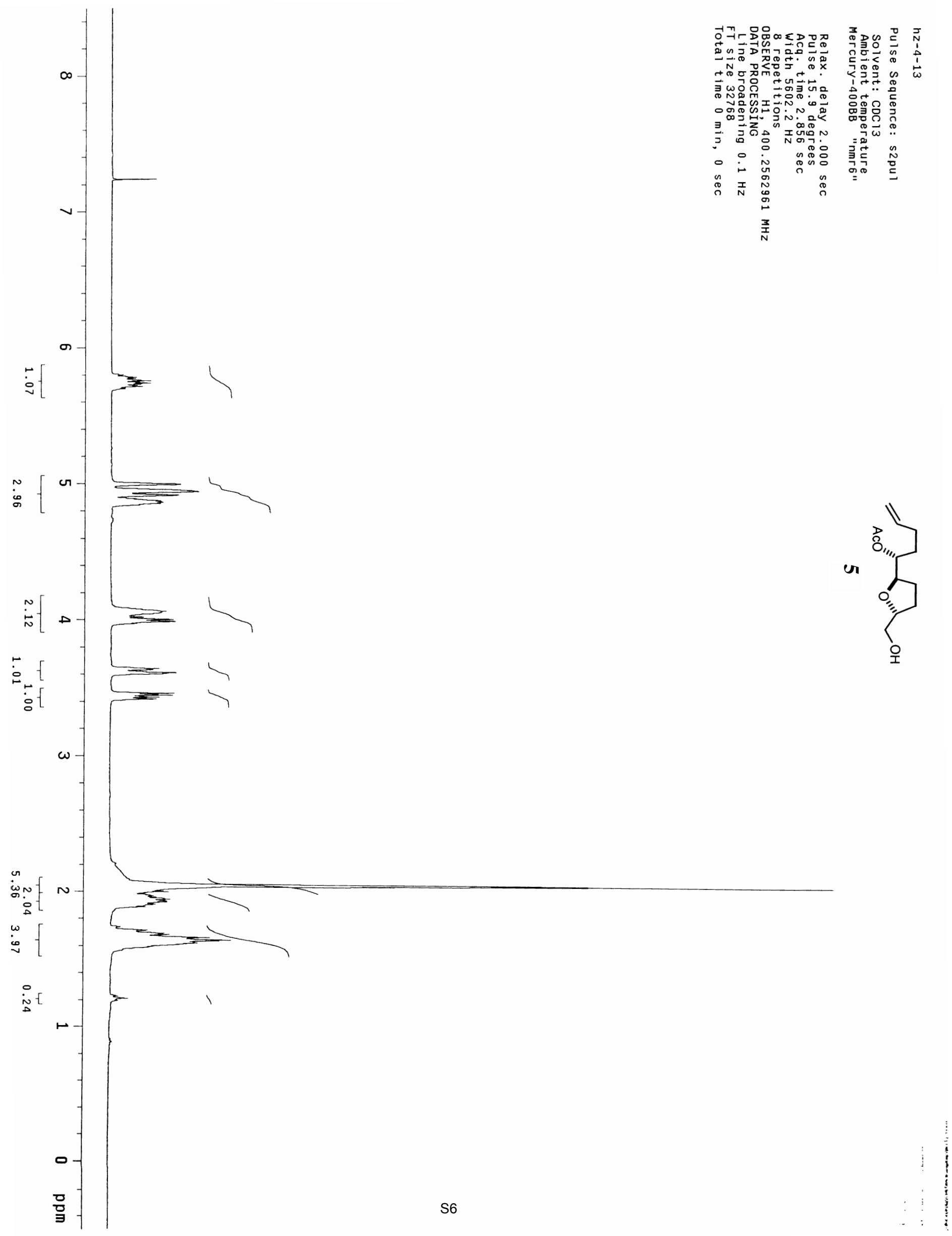



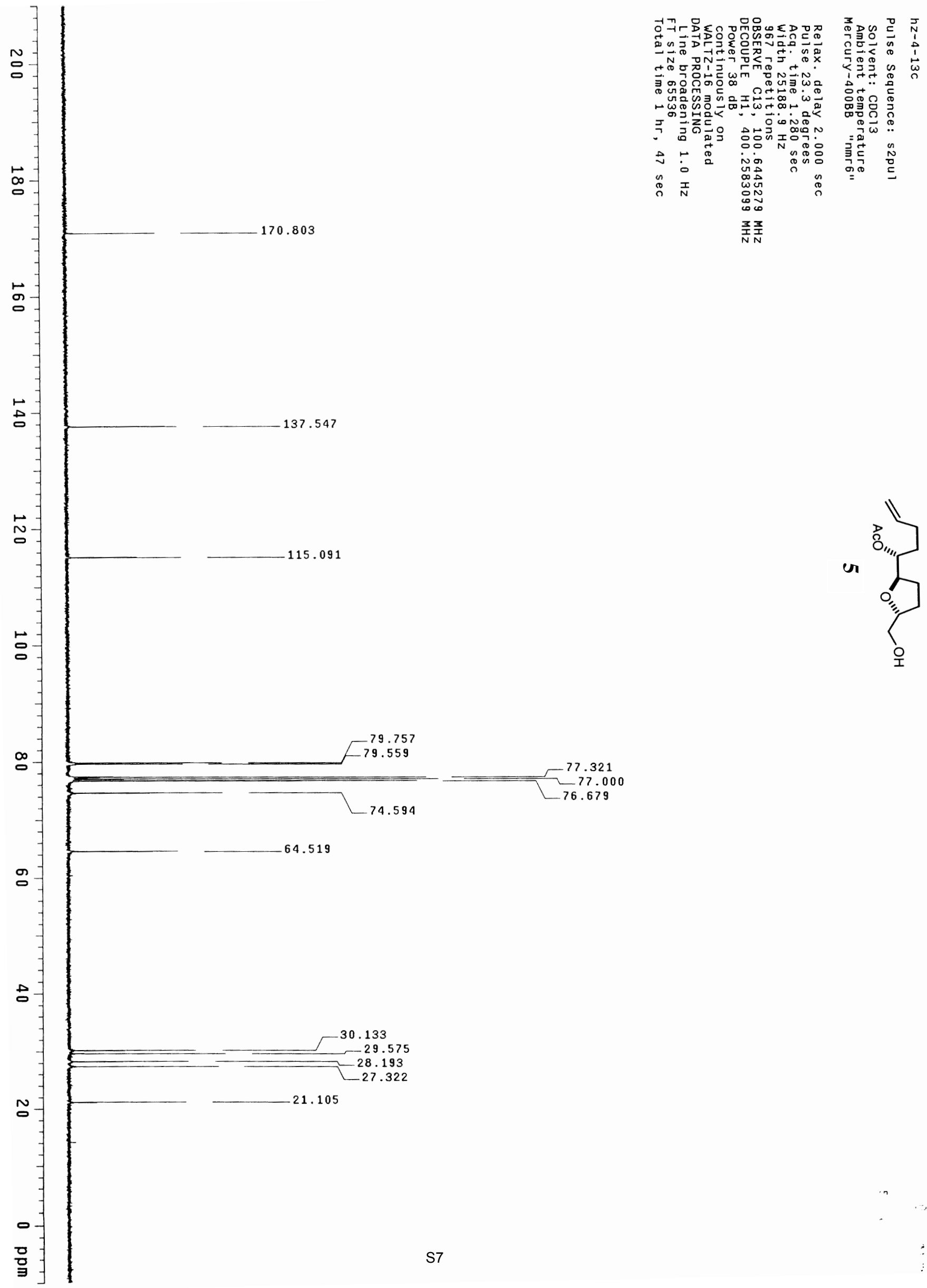

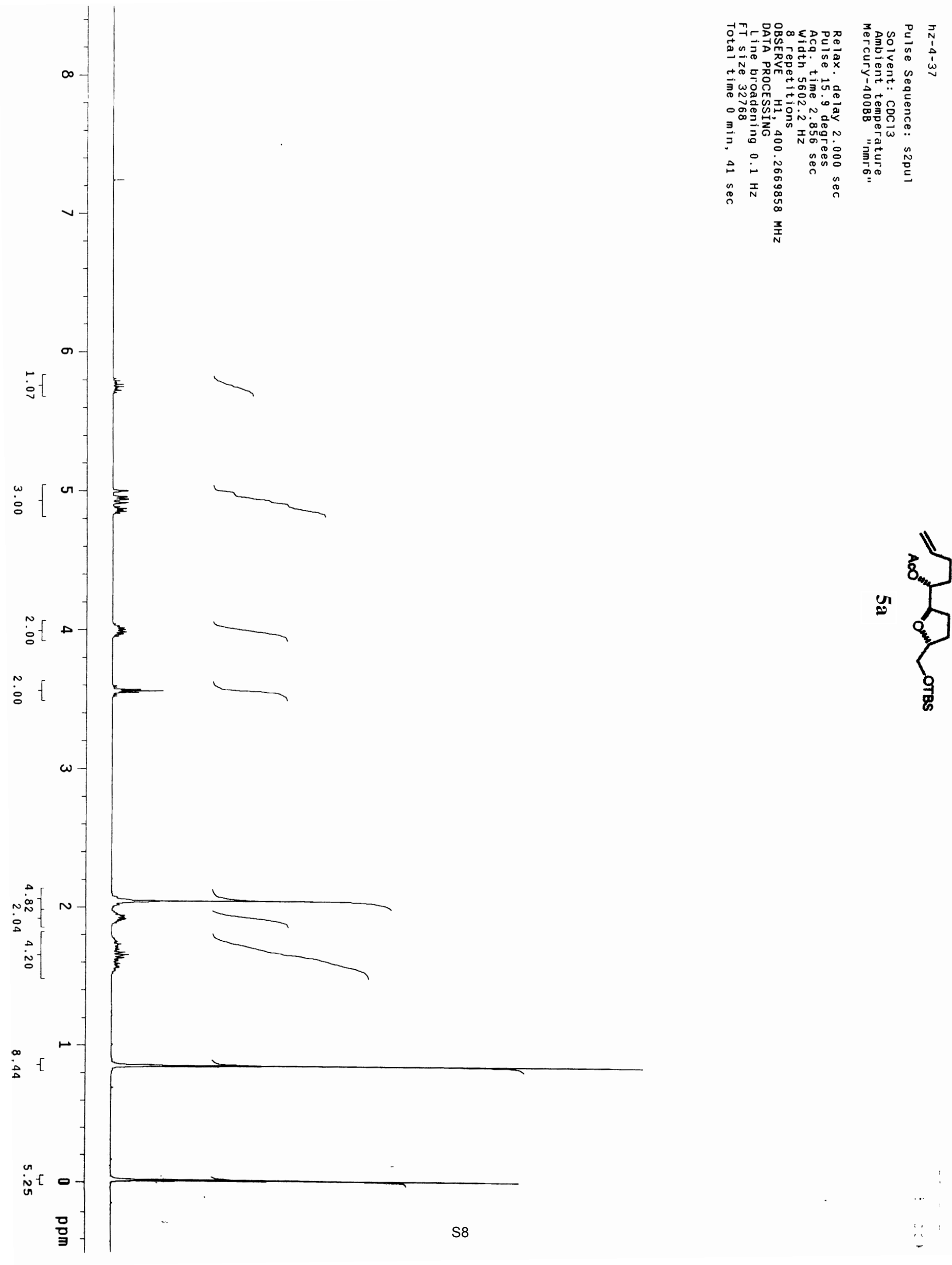

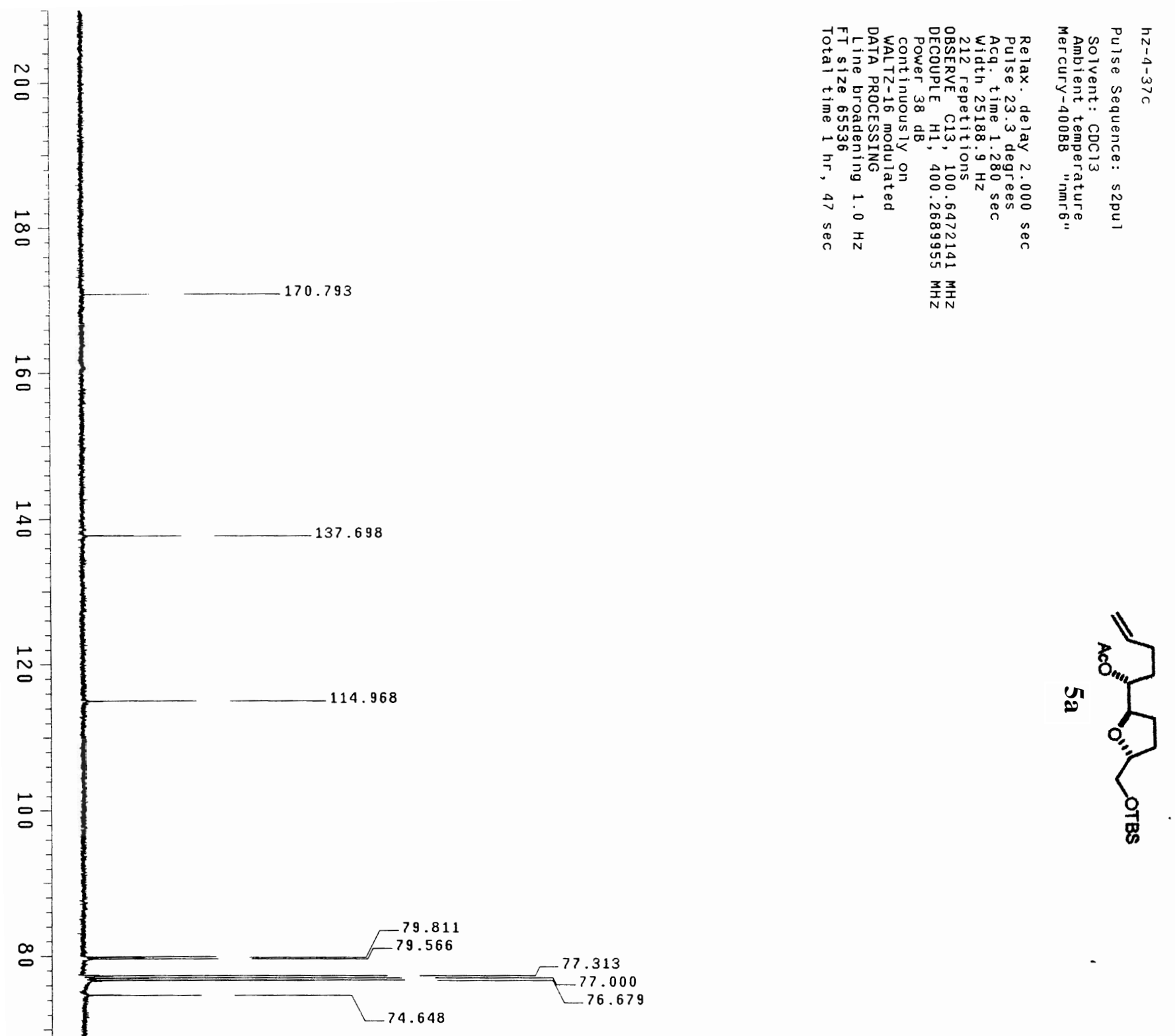

65.581

o

$\therefore$

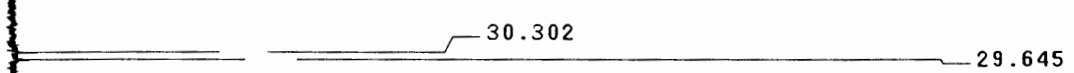

28.049

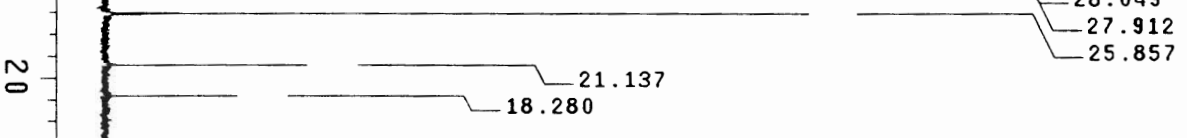

ㅇ- 


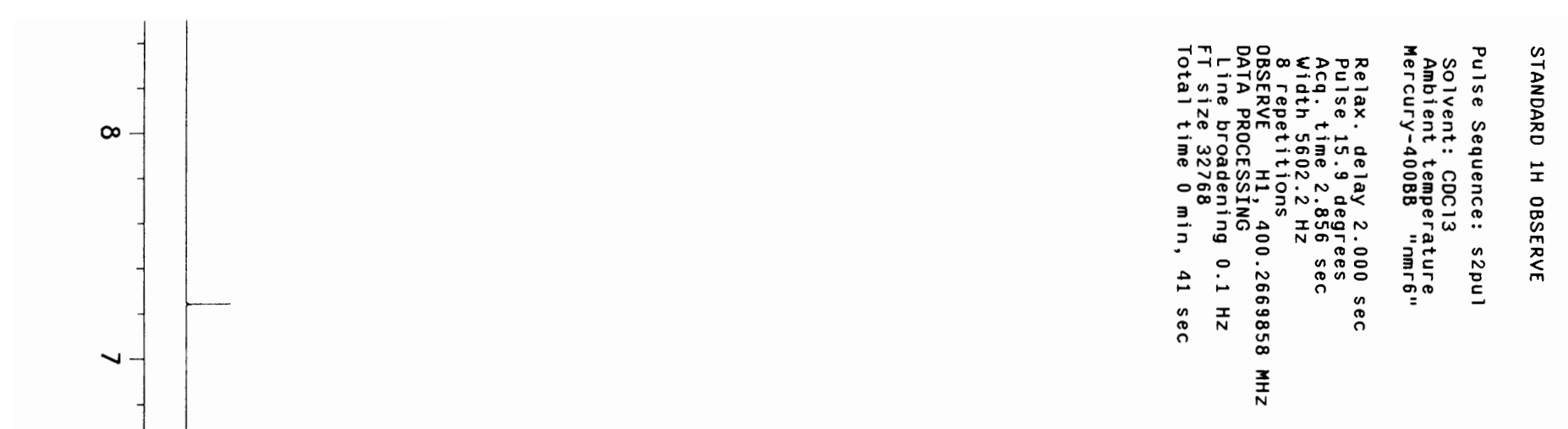




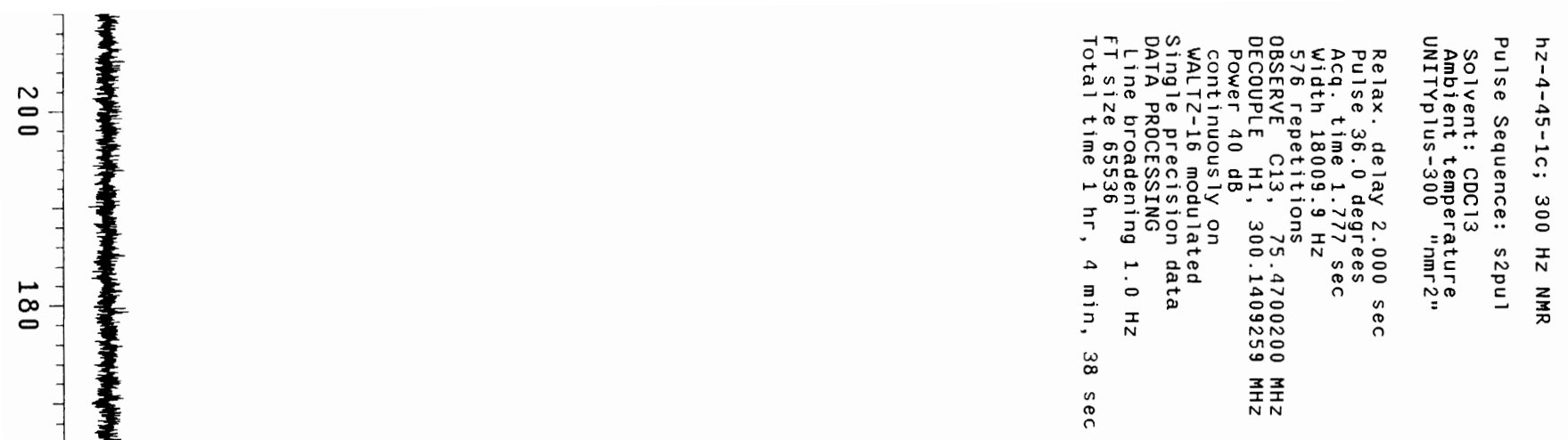
$-138.504$

$\stackrel{\square}{\square}$

品

$\stackrel{\leftarrow}{\sim}$ 114.696



$\infty$

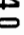

$-32.779$

29.822

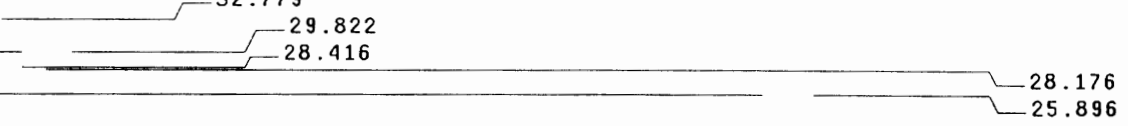

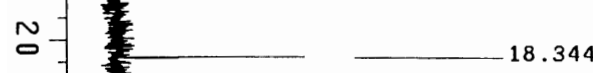

-77.000
76.578

$-65.772$

82.608
79.680

3.315

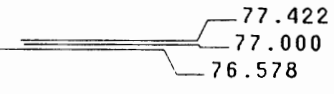

25.896

어 


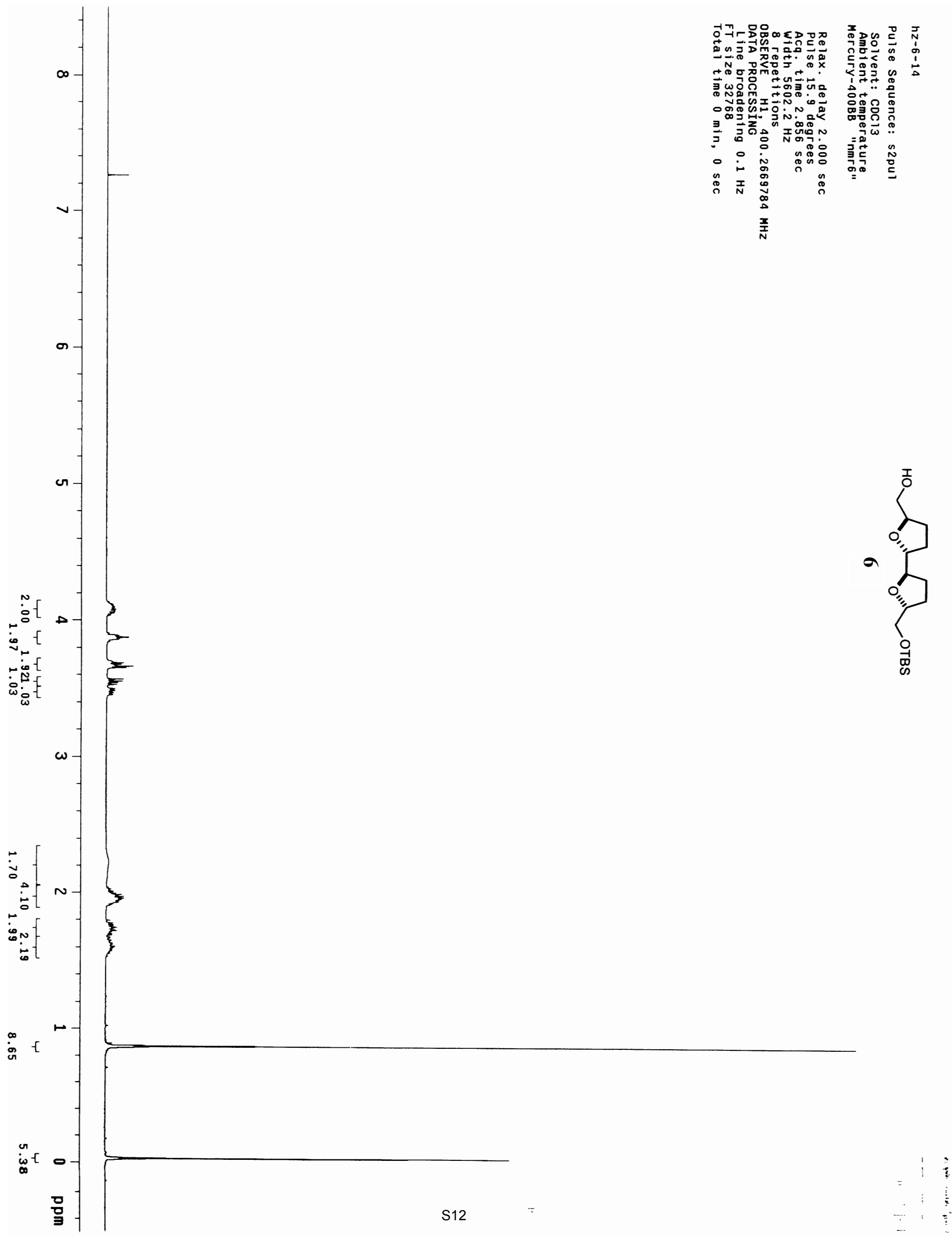




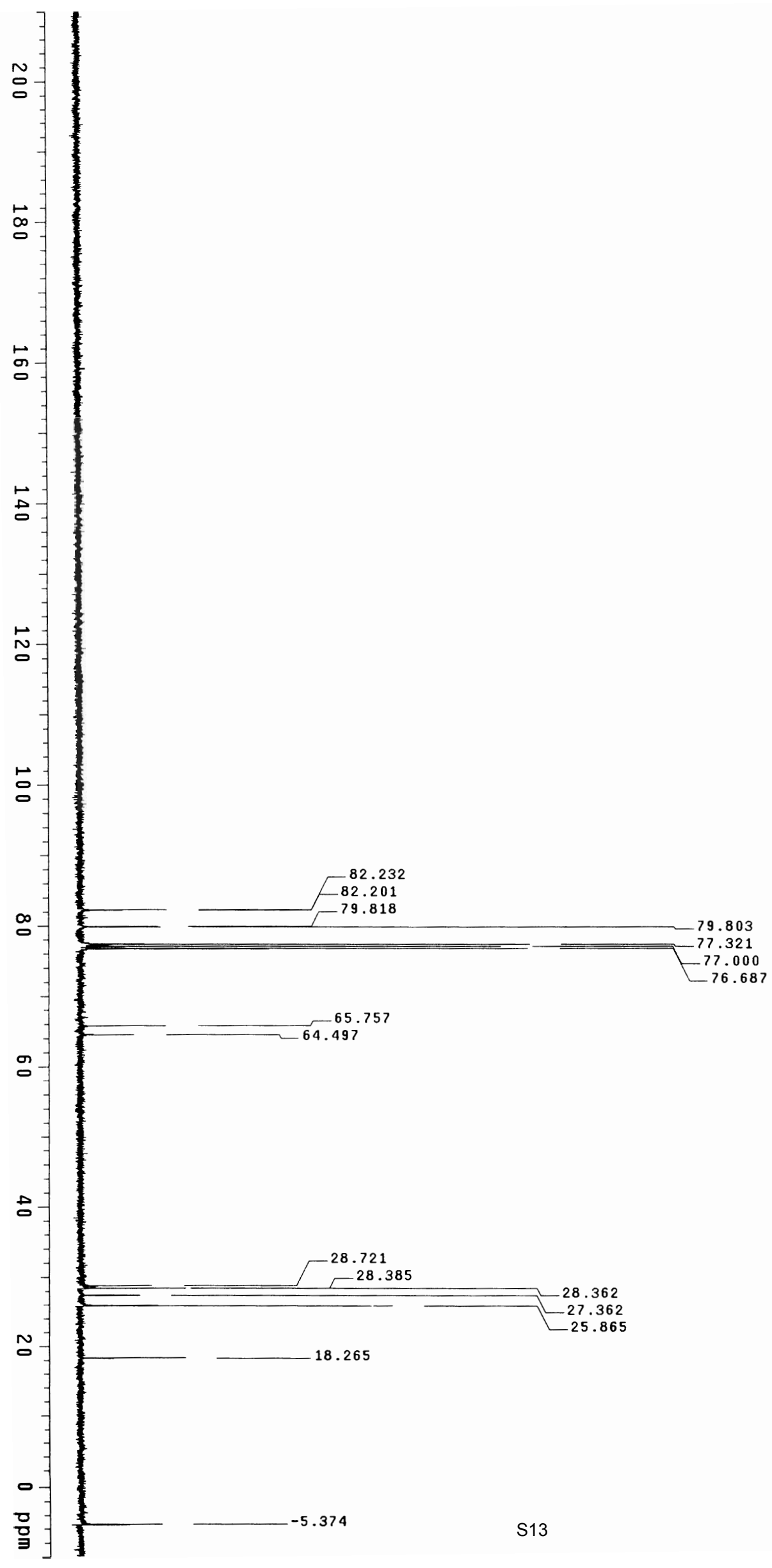

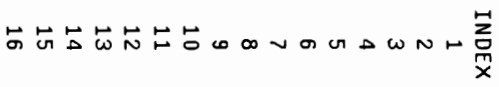

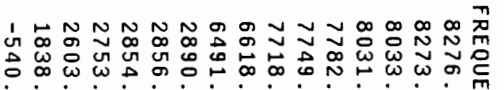

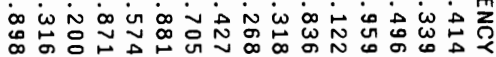

눈 $\omega$
$\sim$
$\sim$
$\sim$

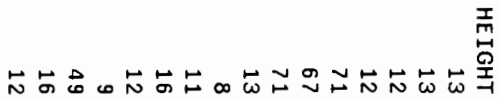

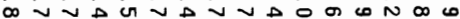

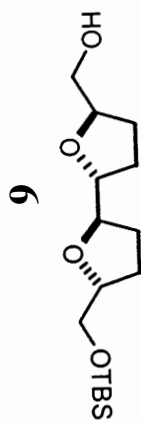





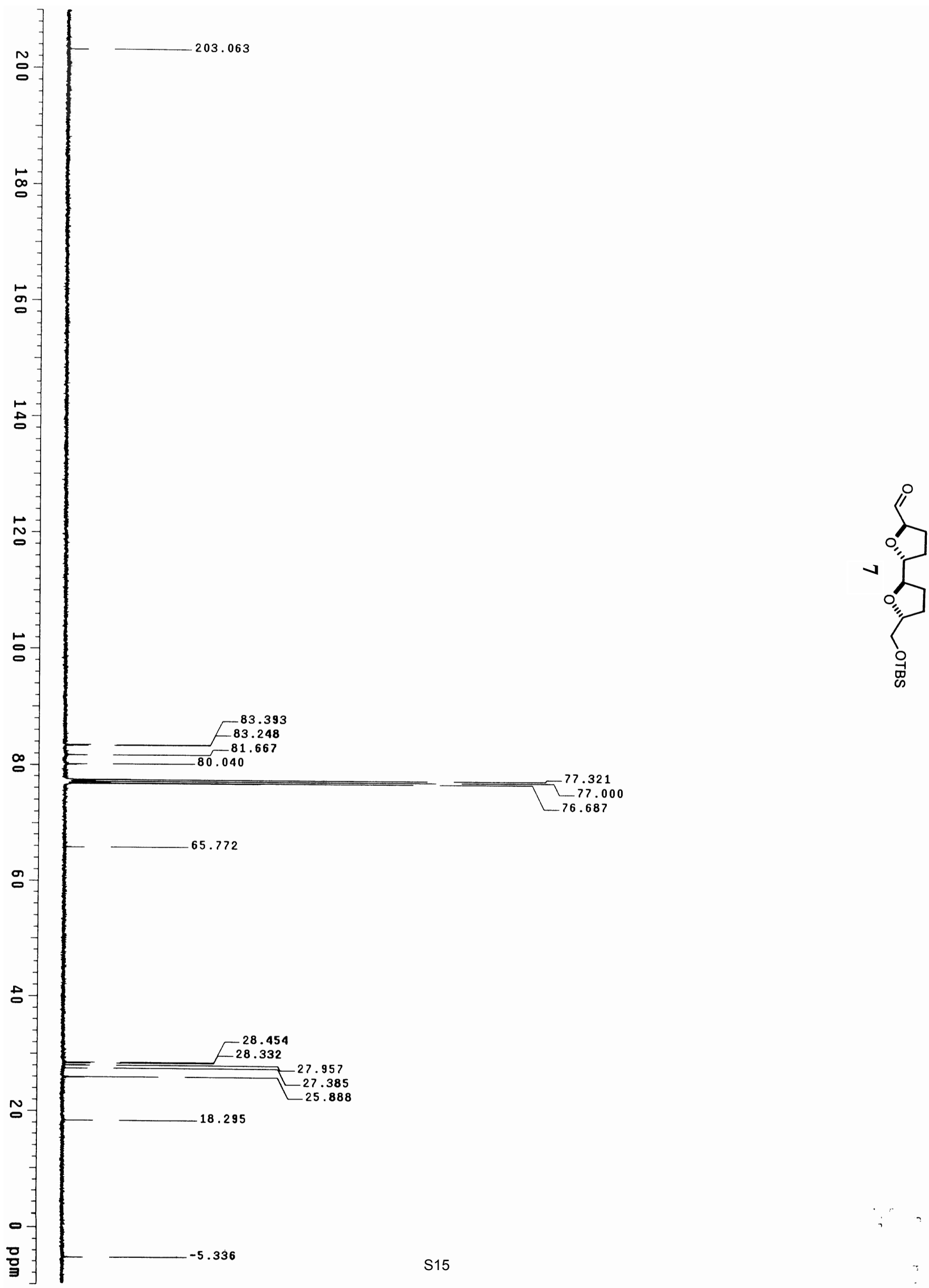

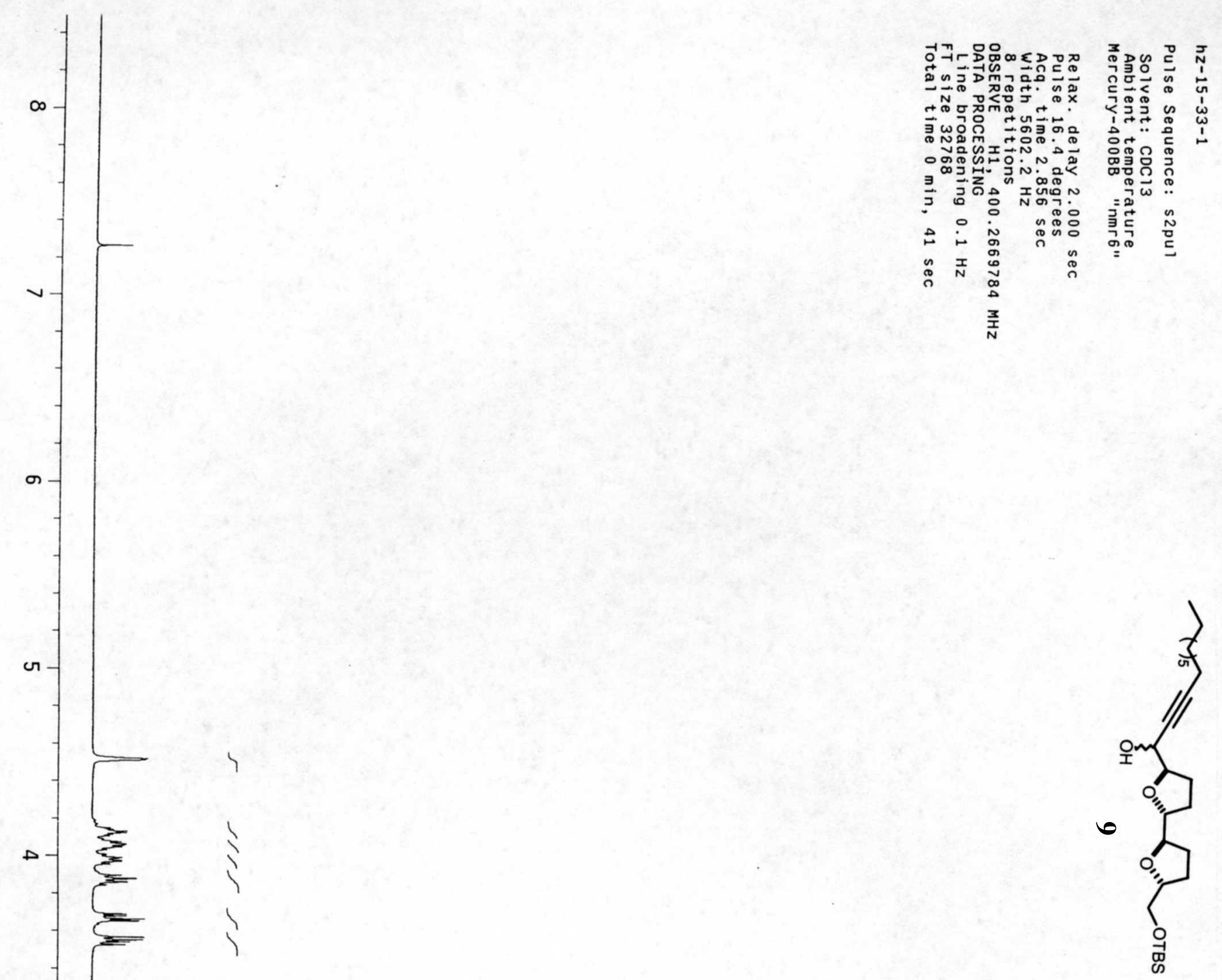

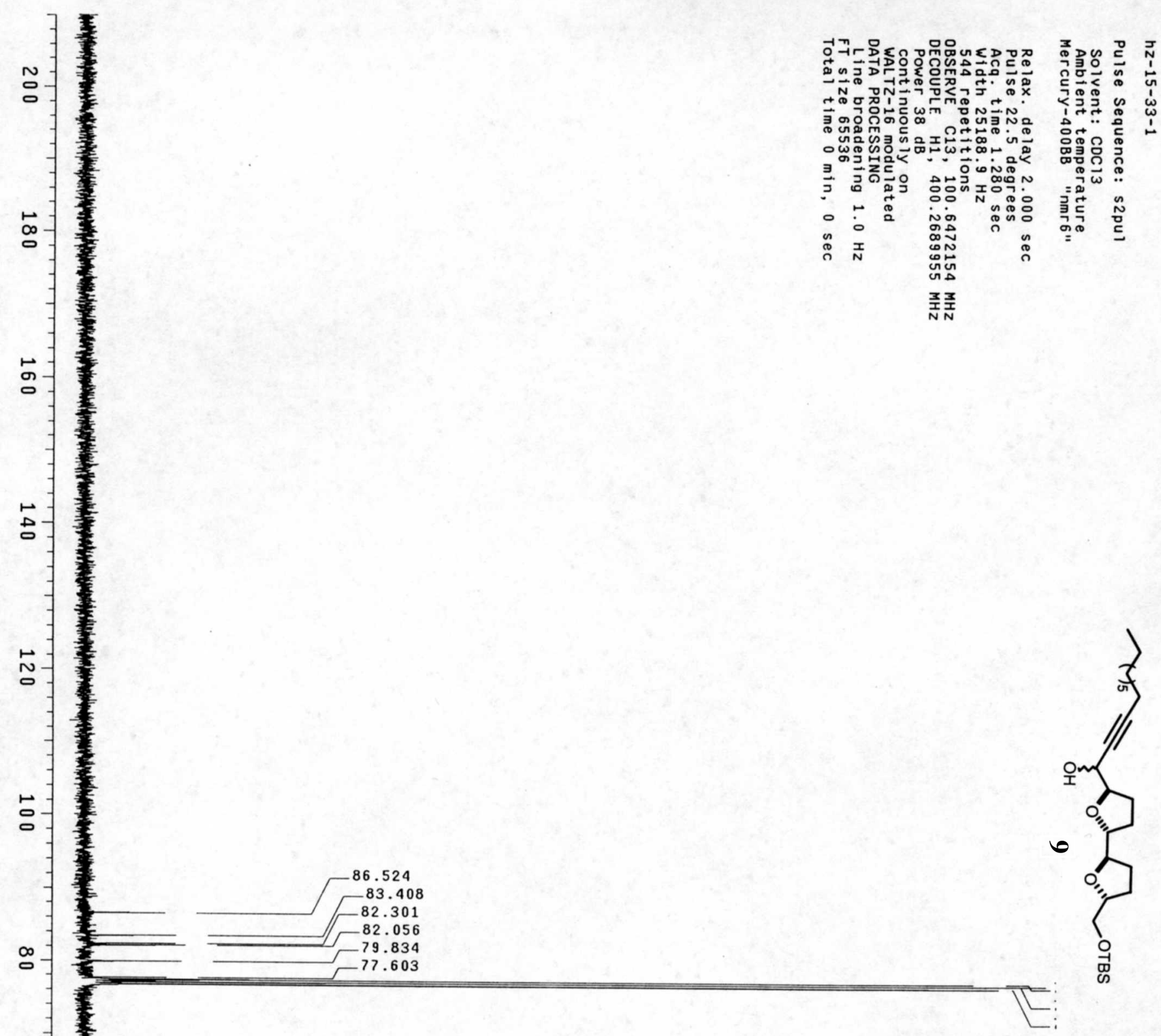

o

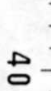

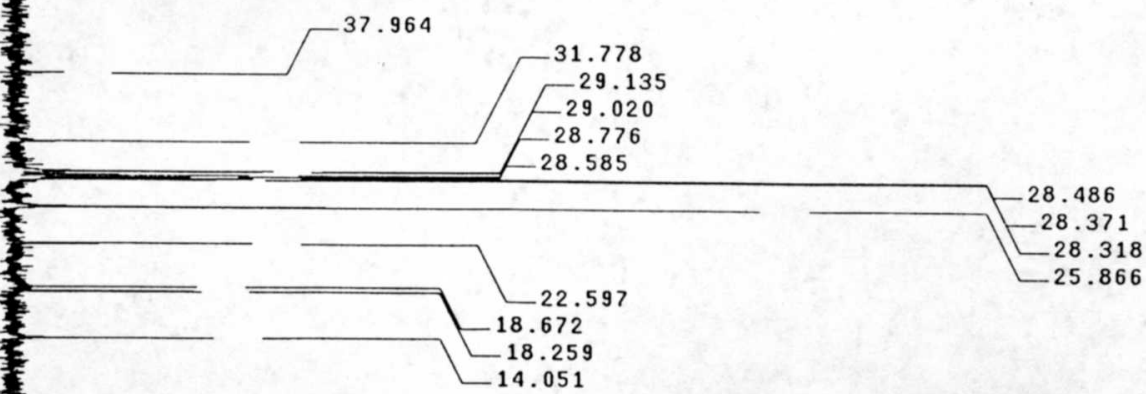

啰 


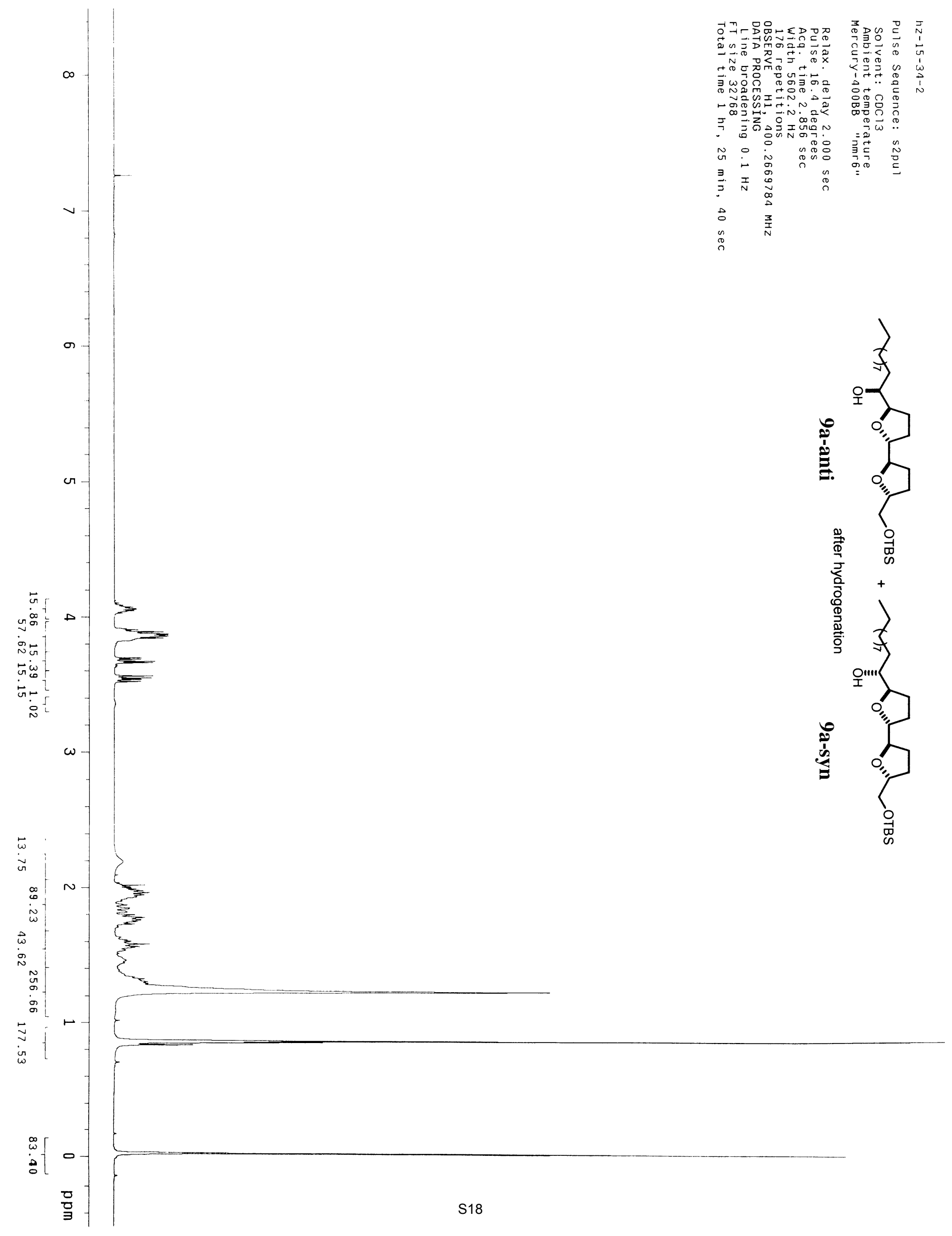



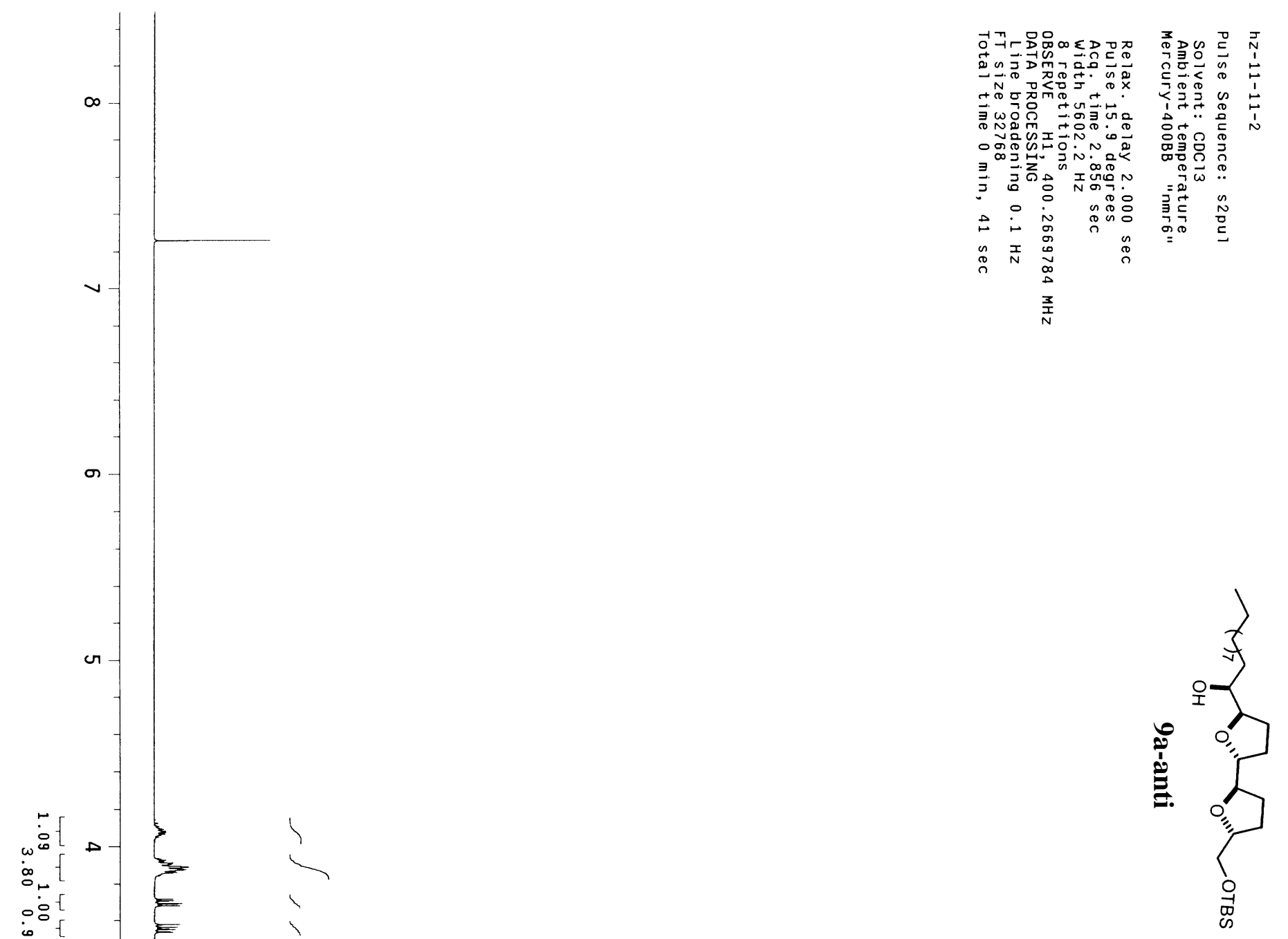

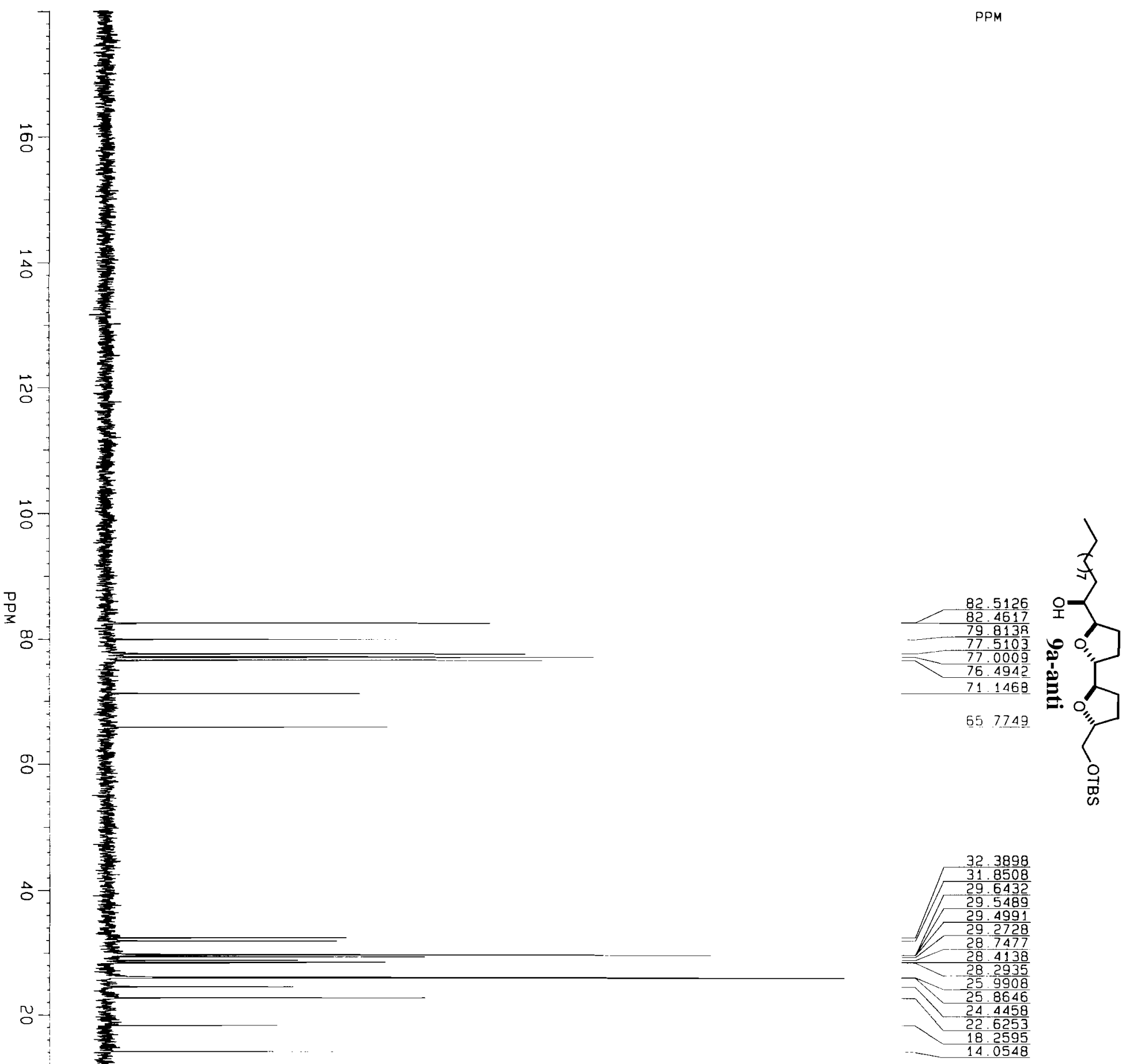

$-5 \quad 3750$

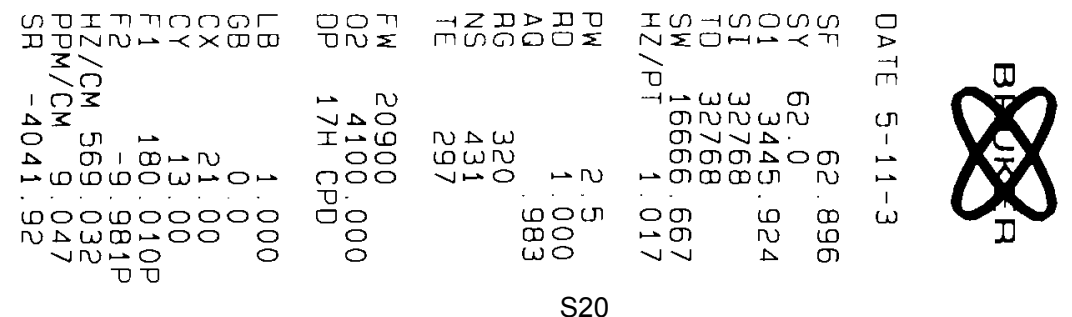





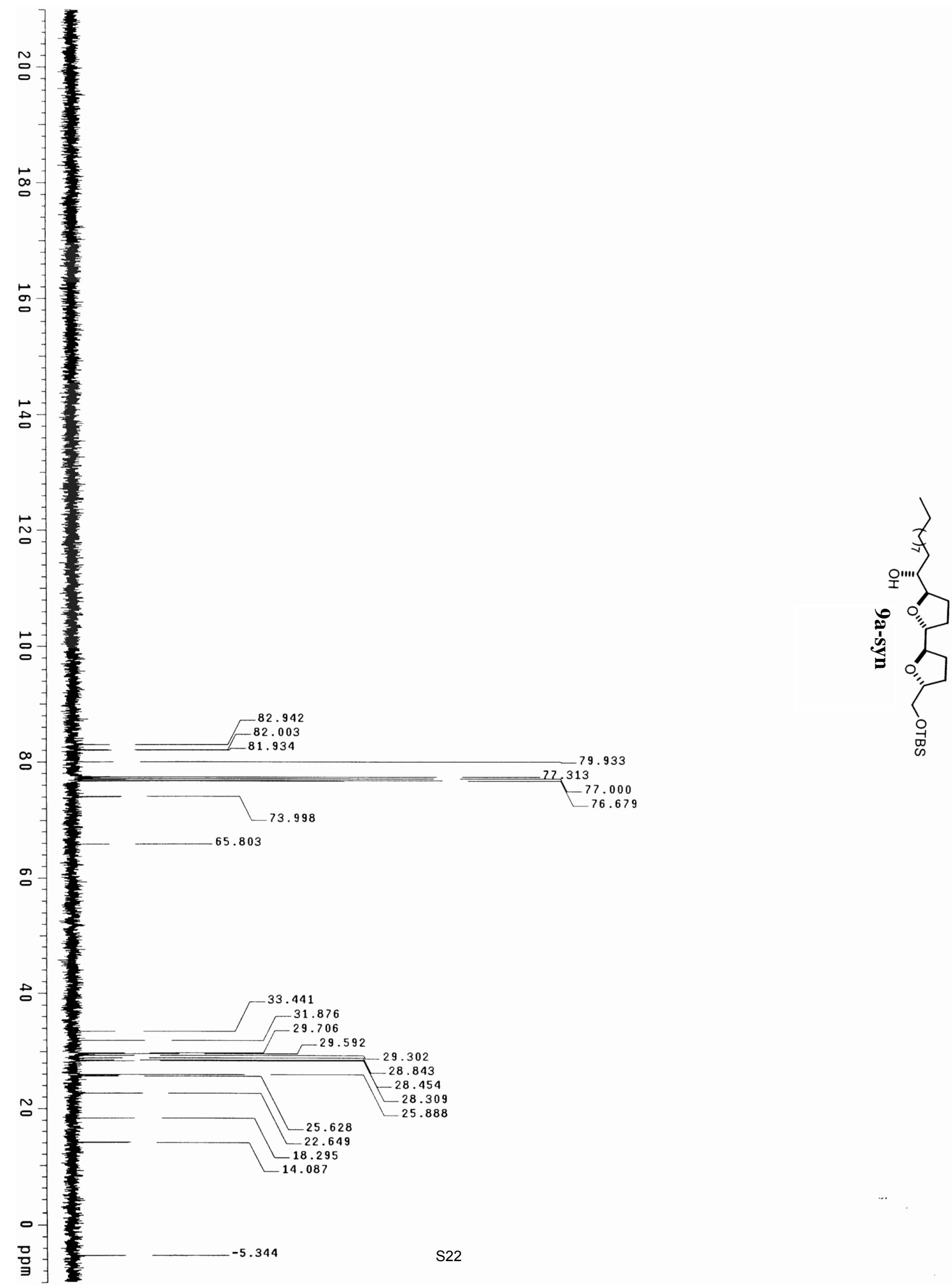

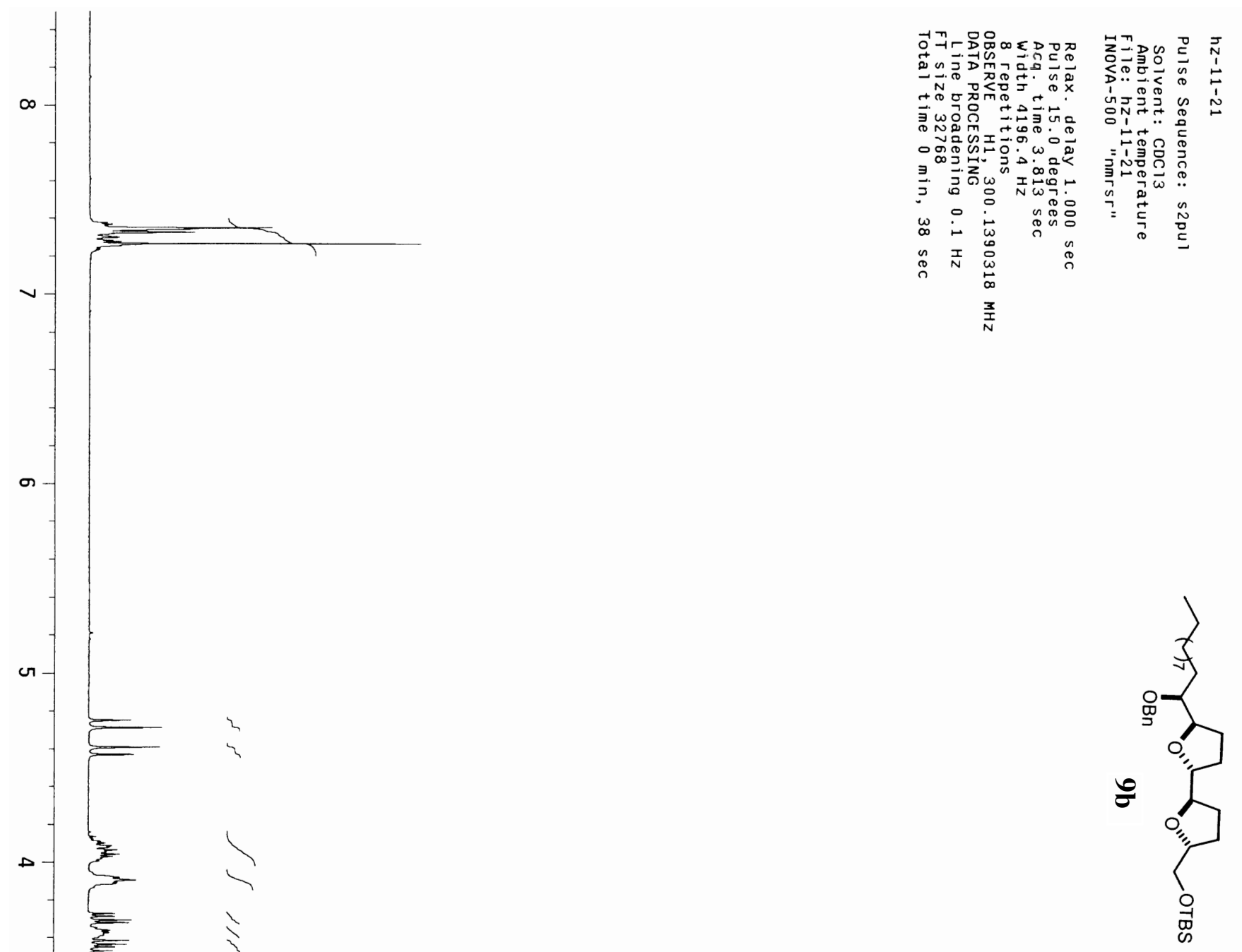

믈 

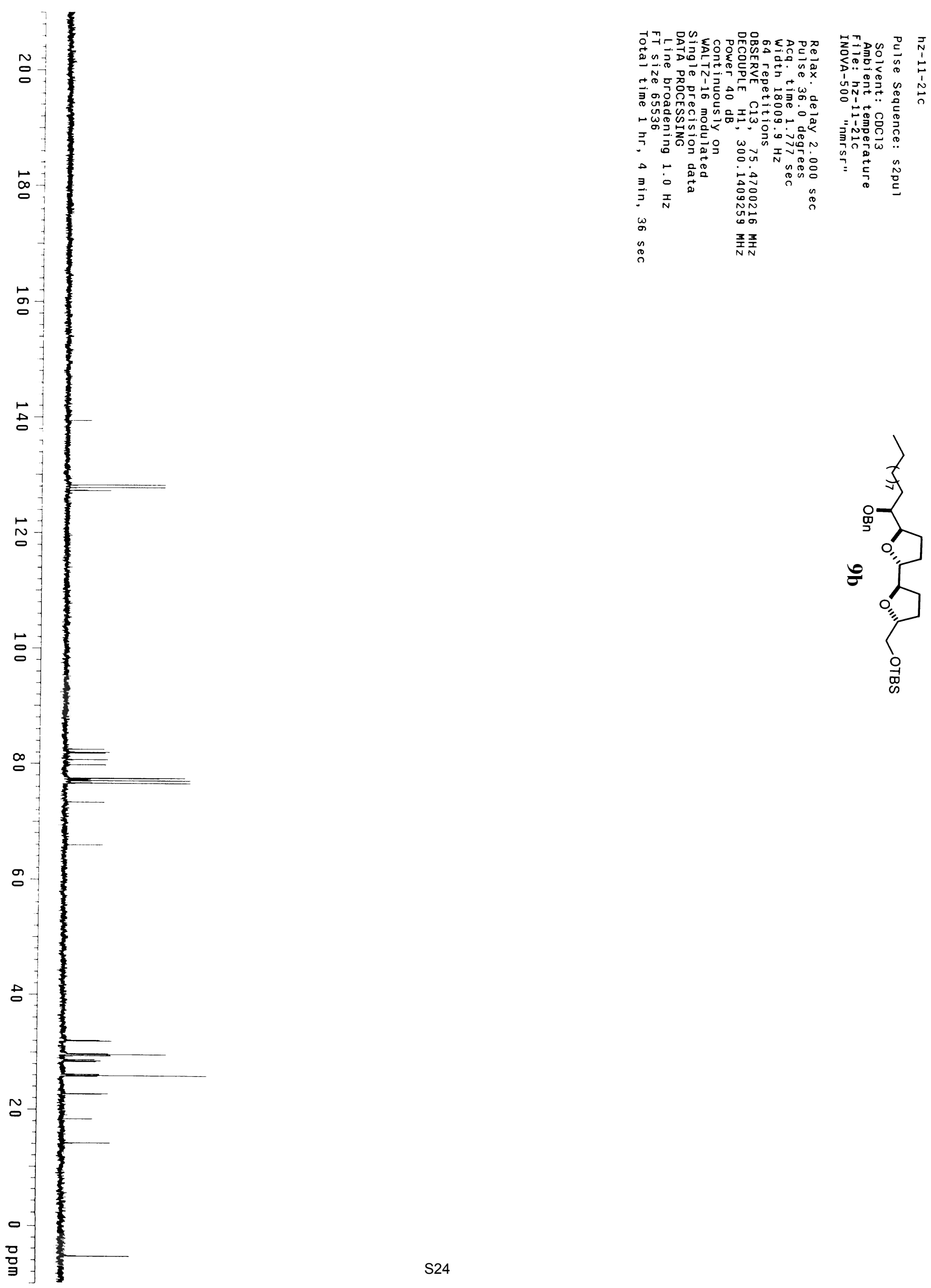


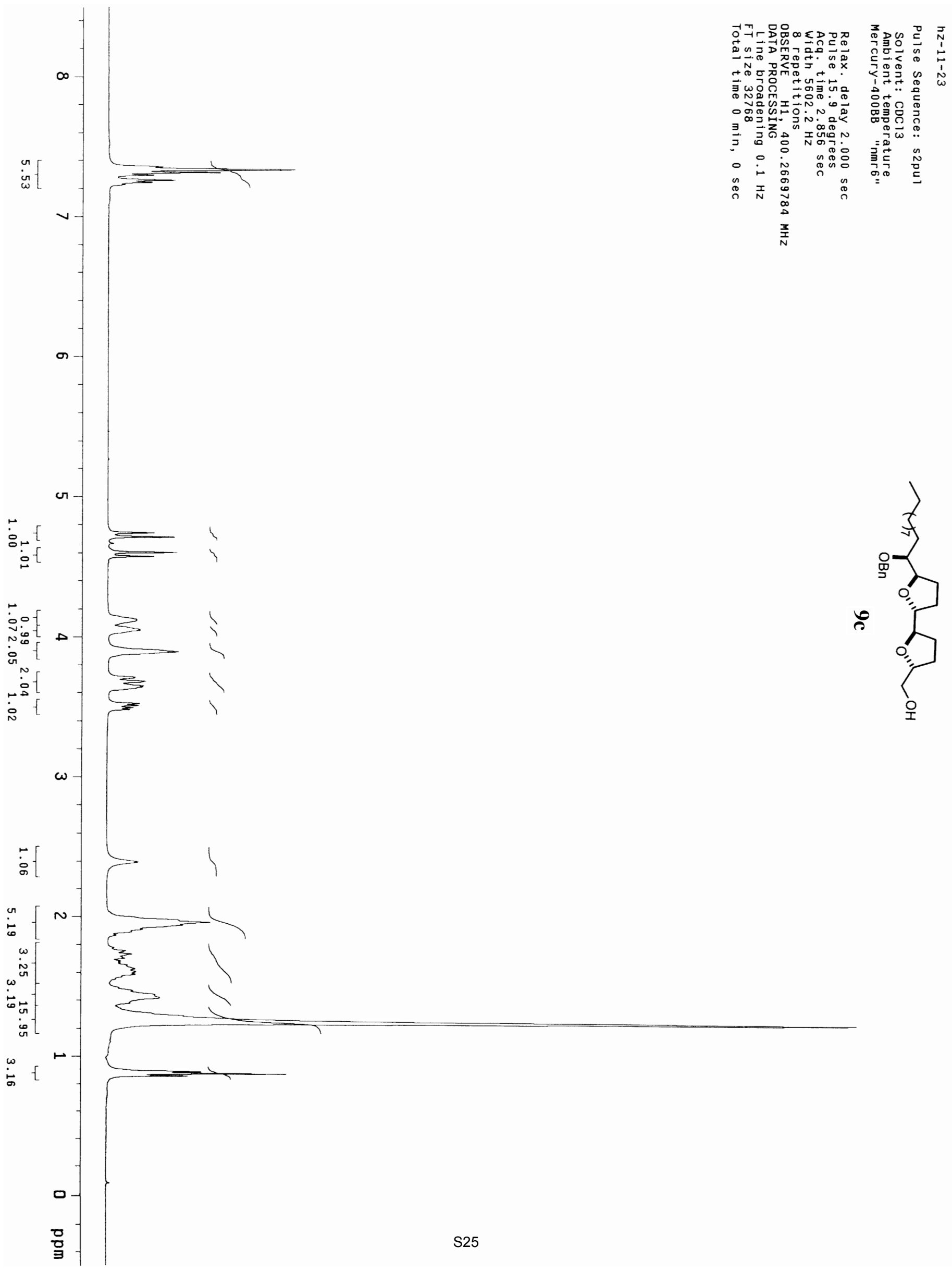




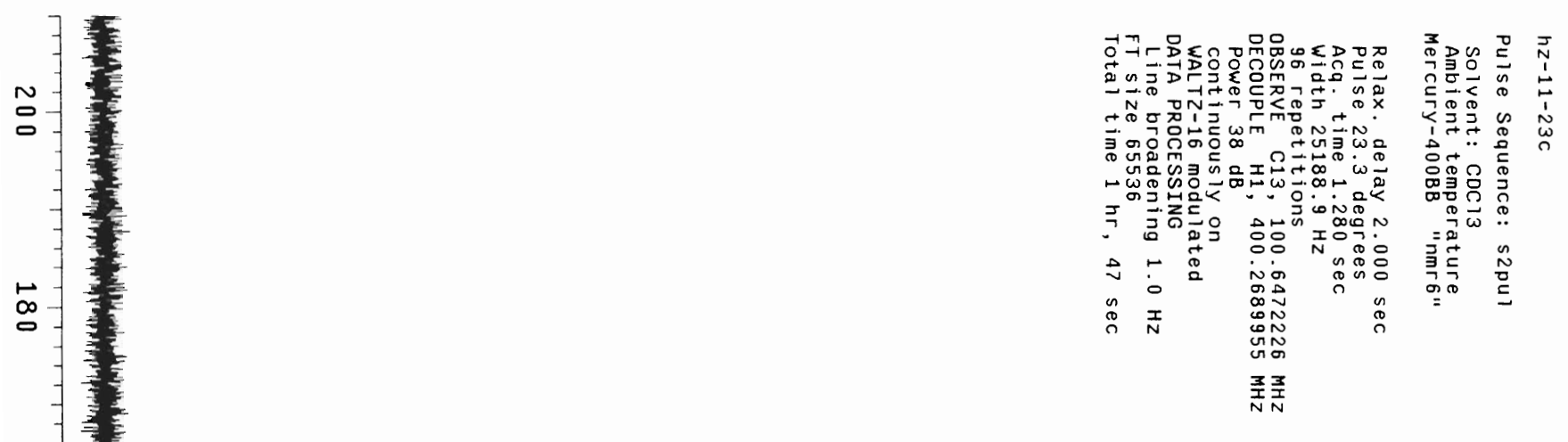

$-139.233$

$-128.112$

No

욤

$\stackrel{\infty}{0}$

吕

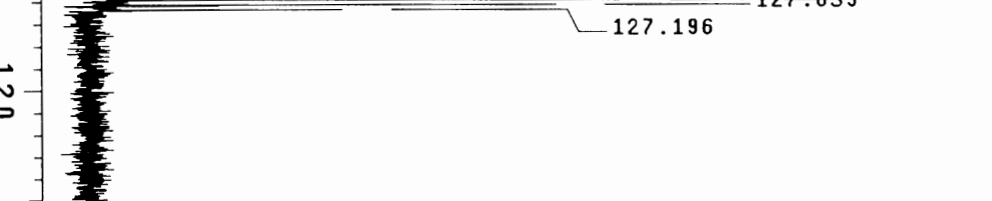

$\infty-1$

$-82.606$

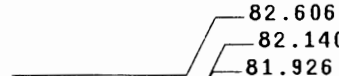

$-80.475$

a

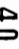

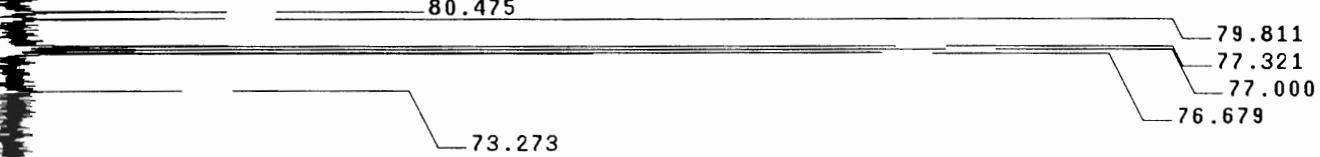

64.466

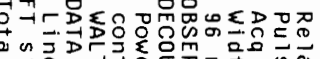

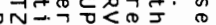

.

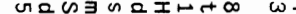

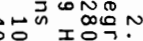

Nंo
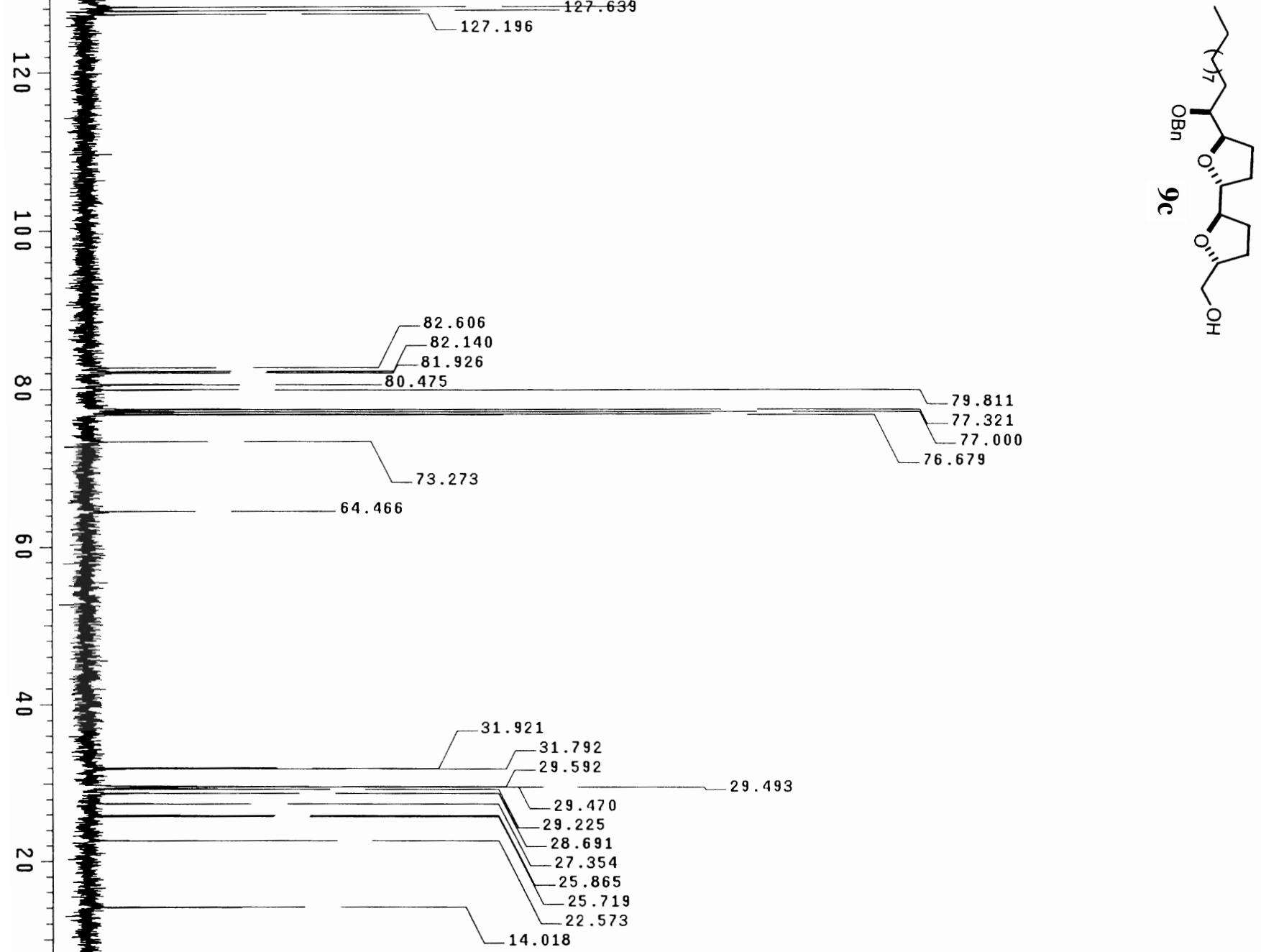

口-1 


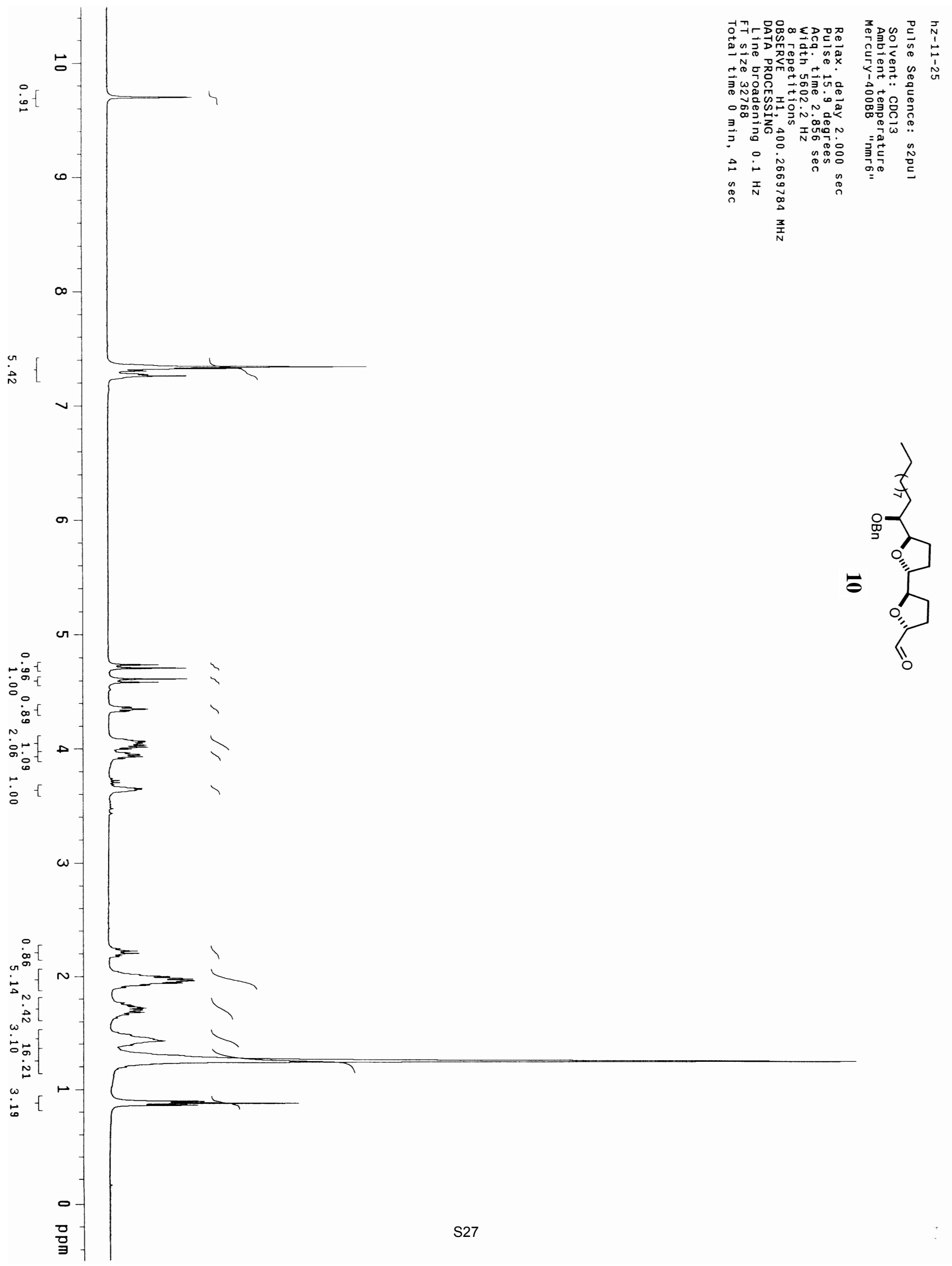



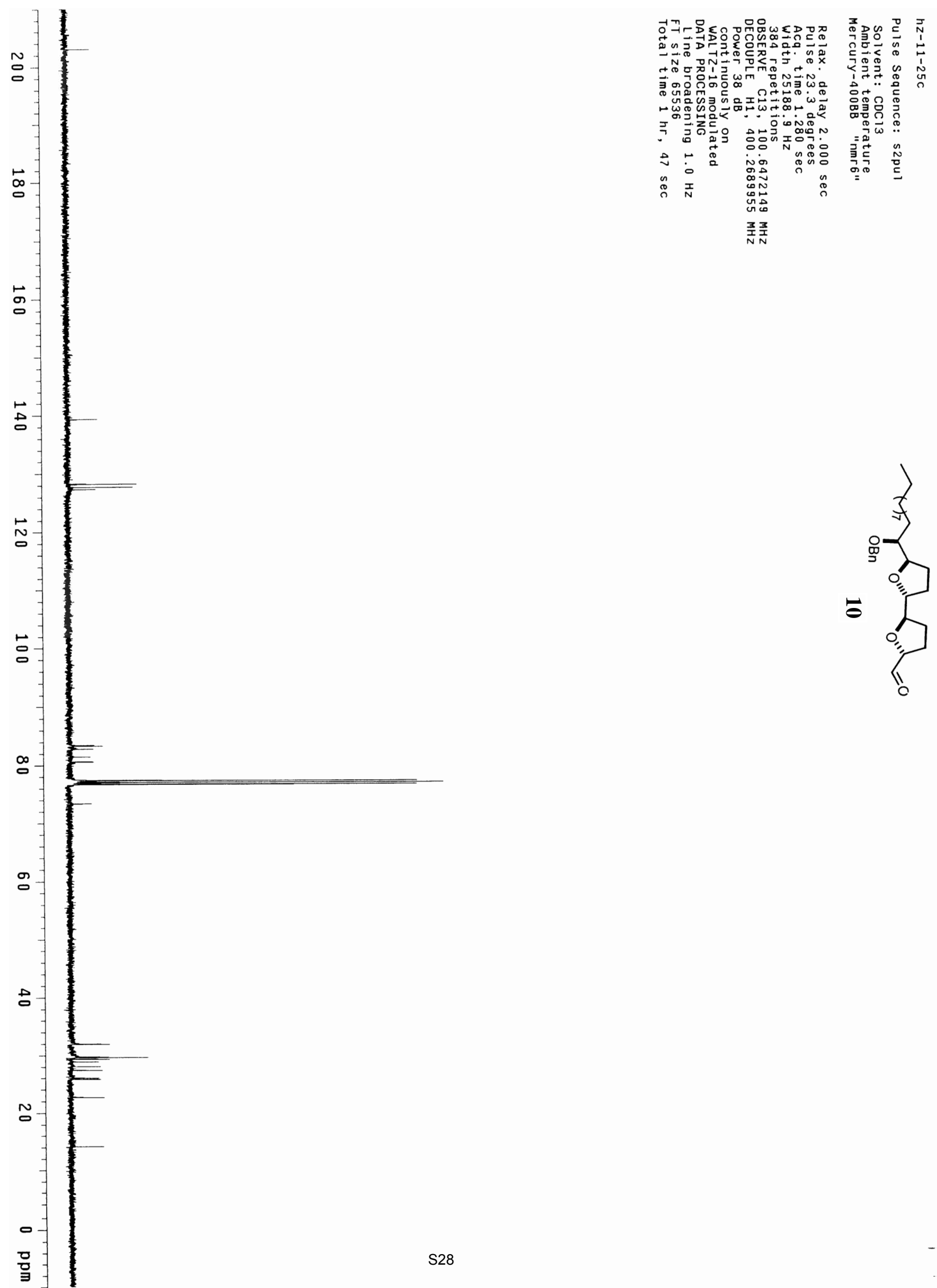


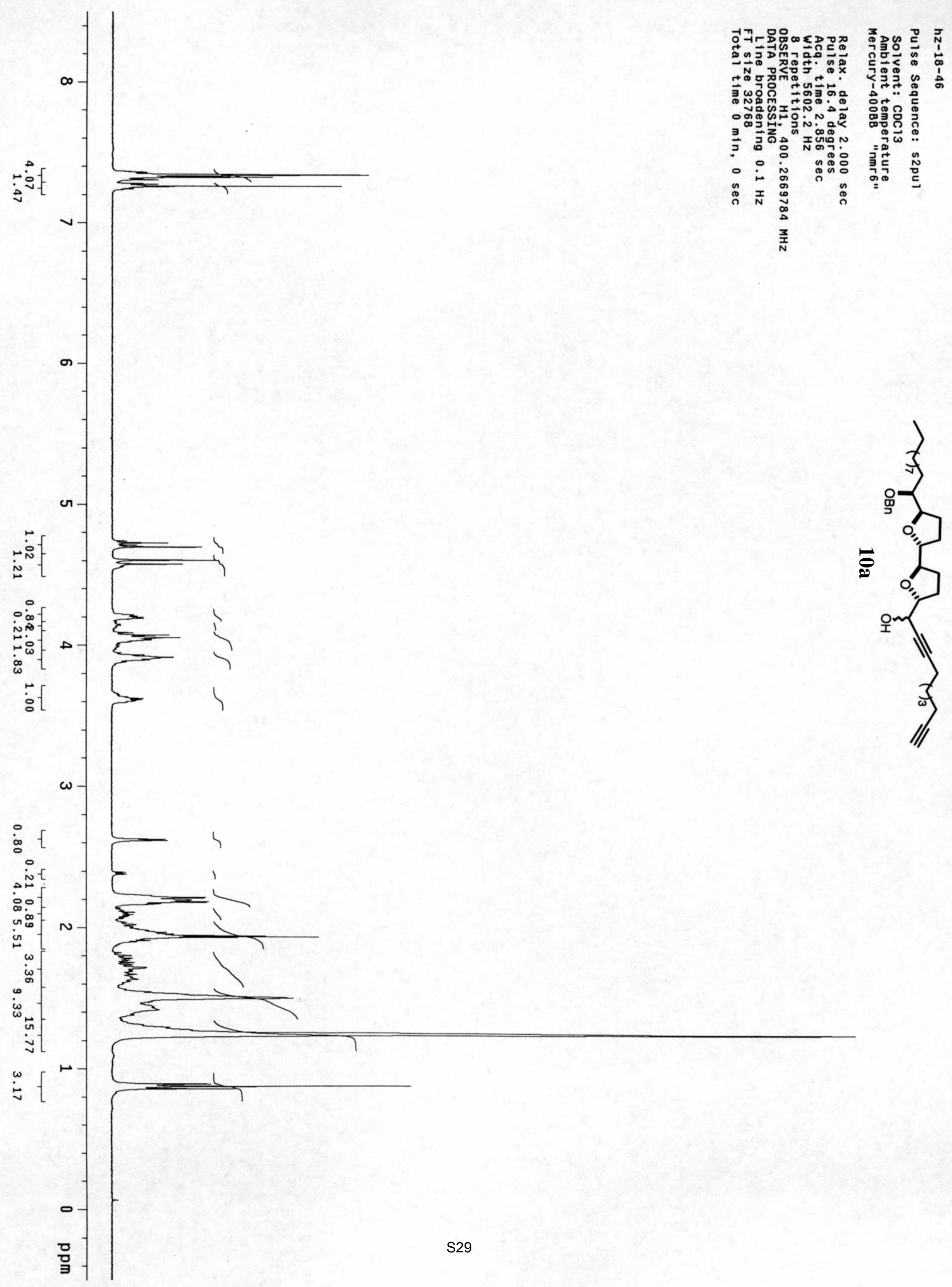




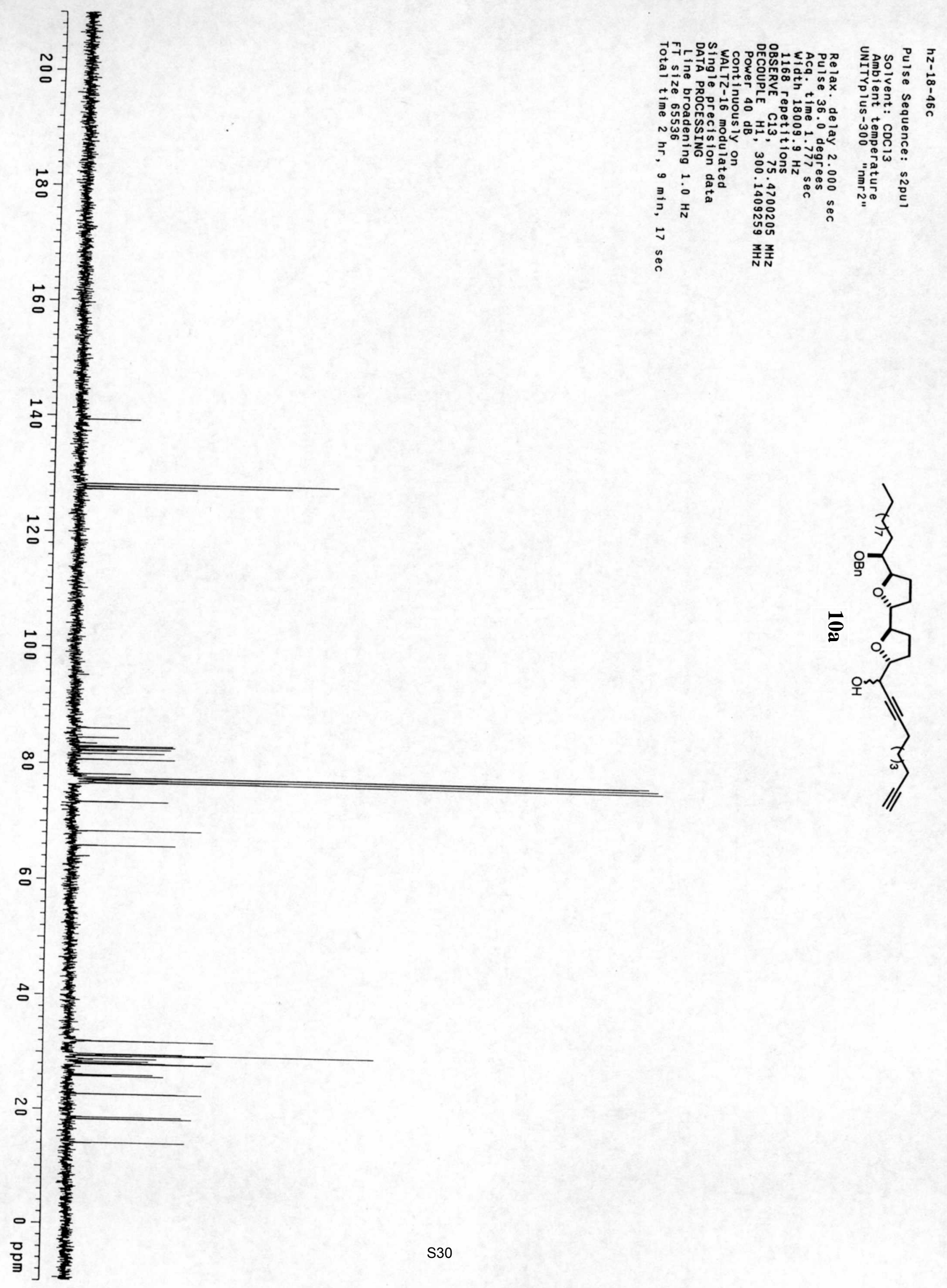




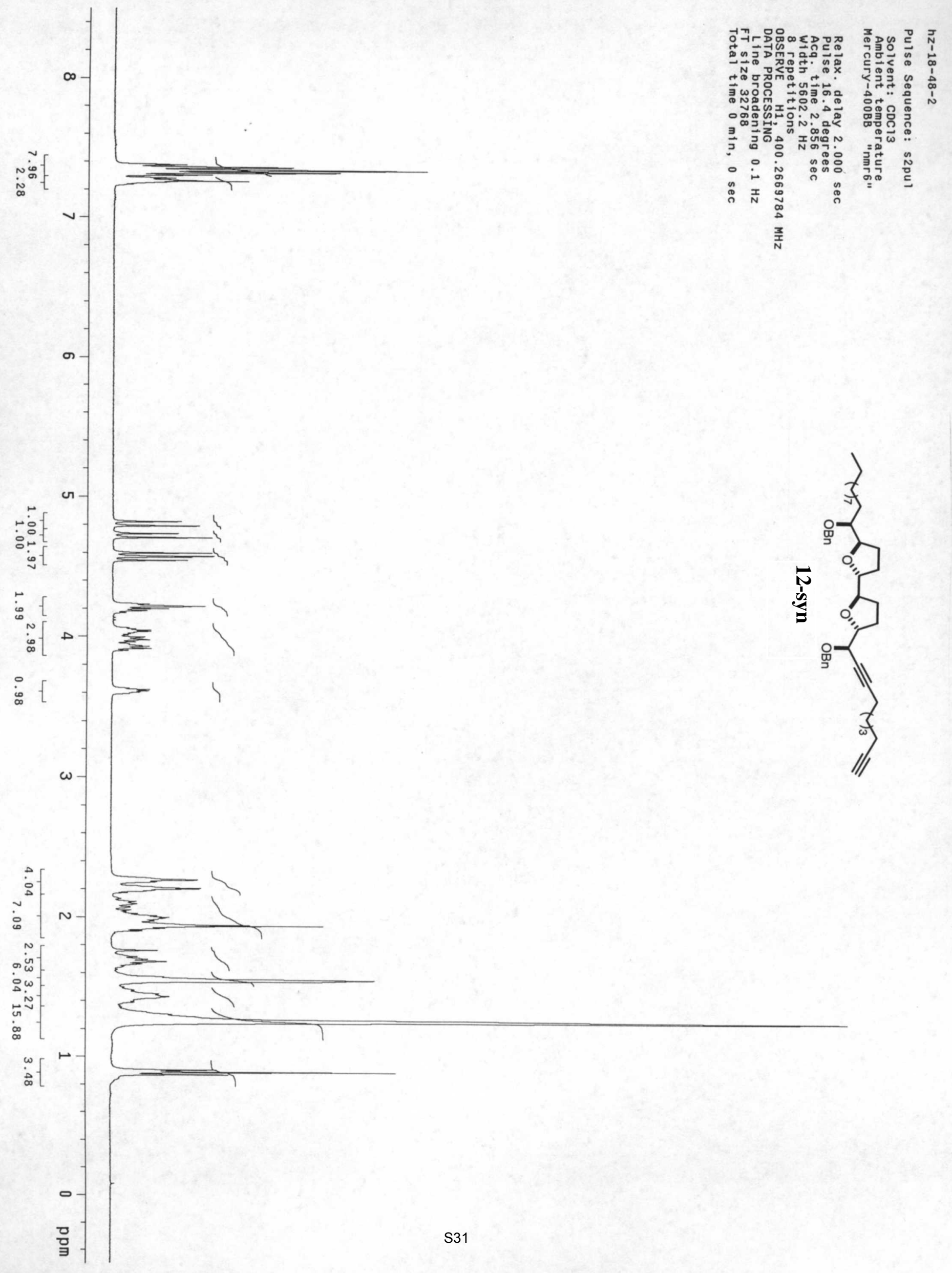




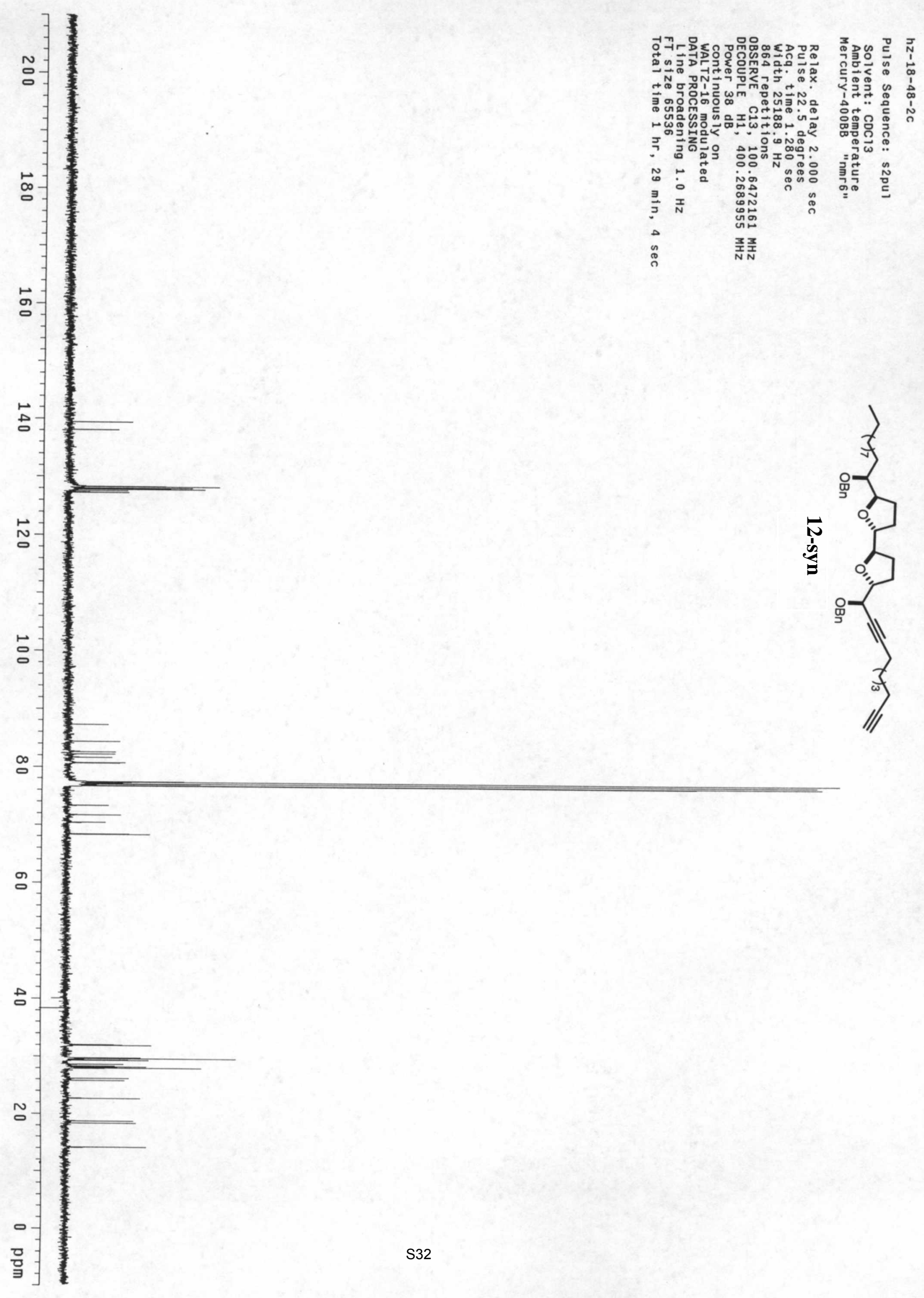




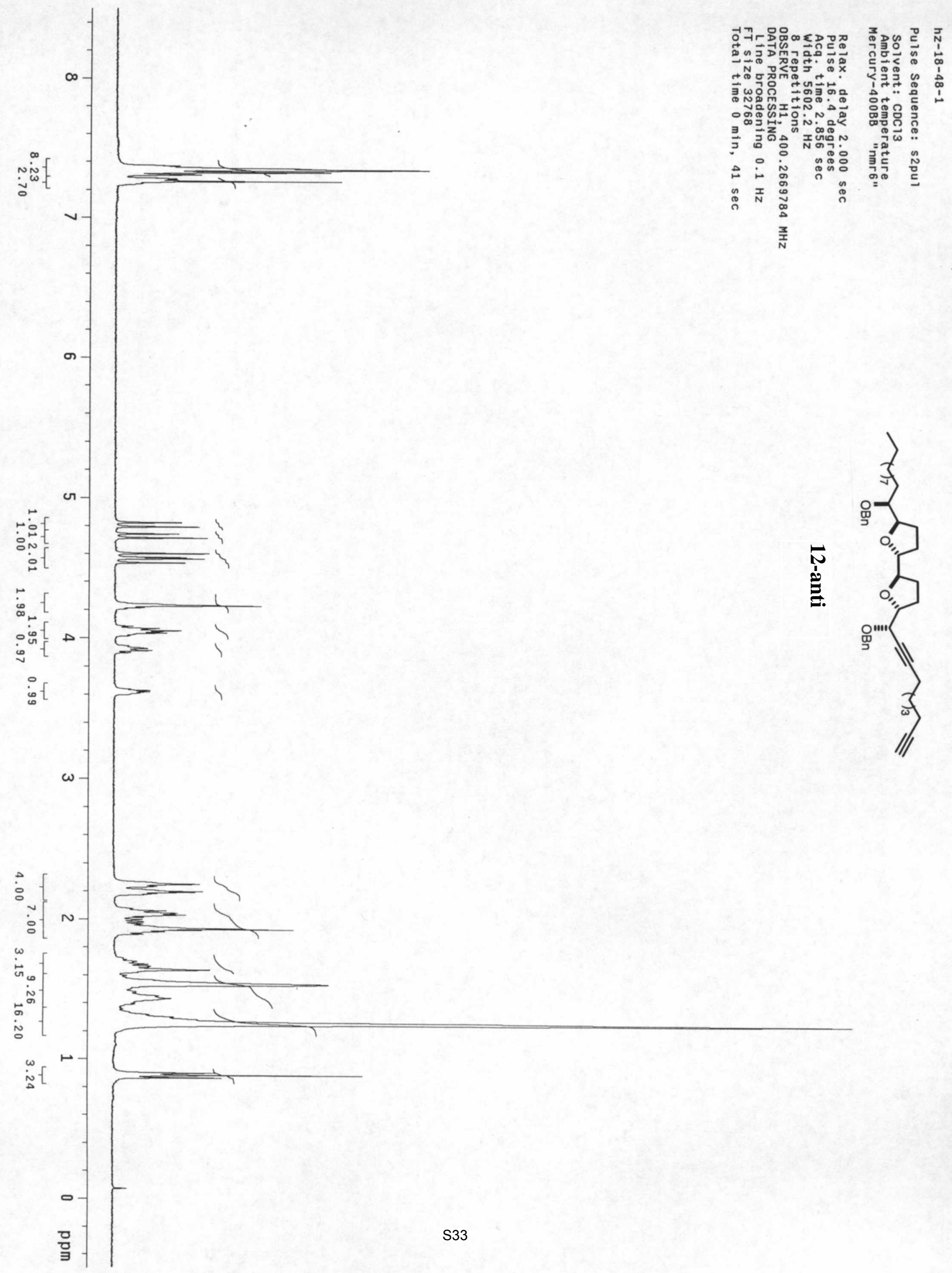









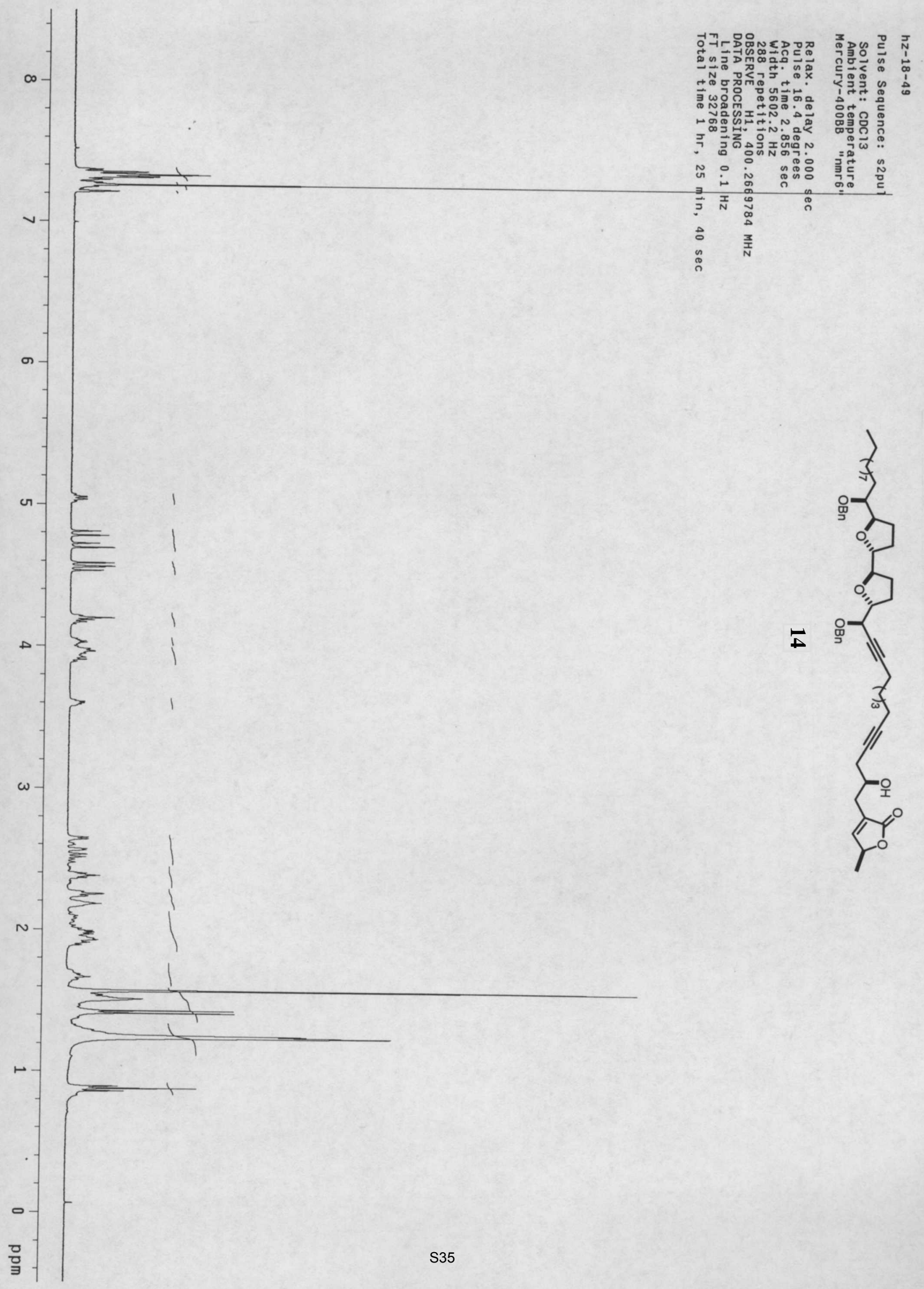




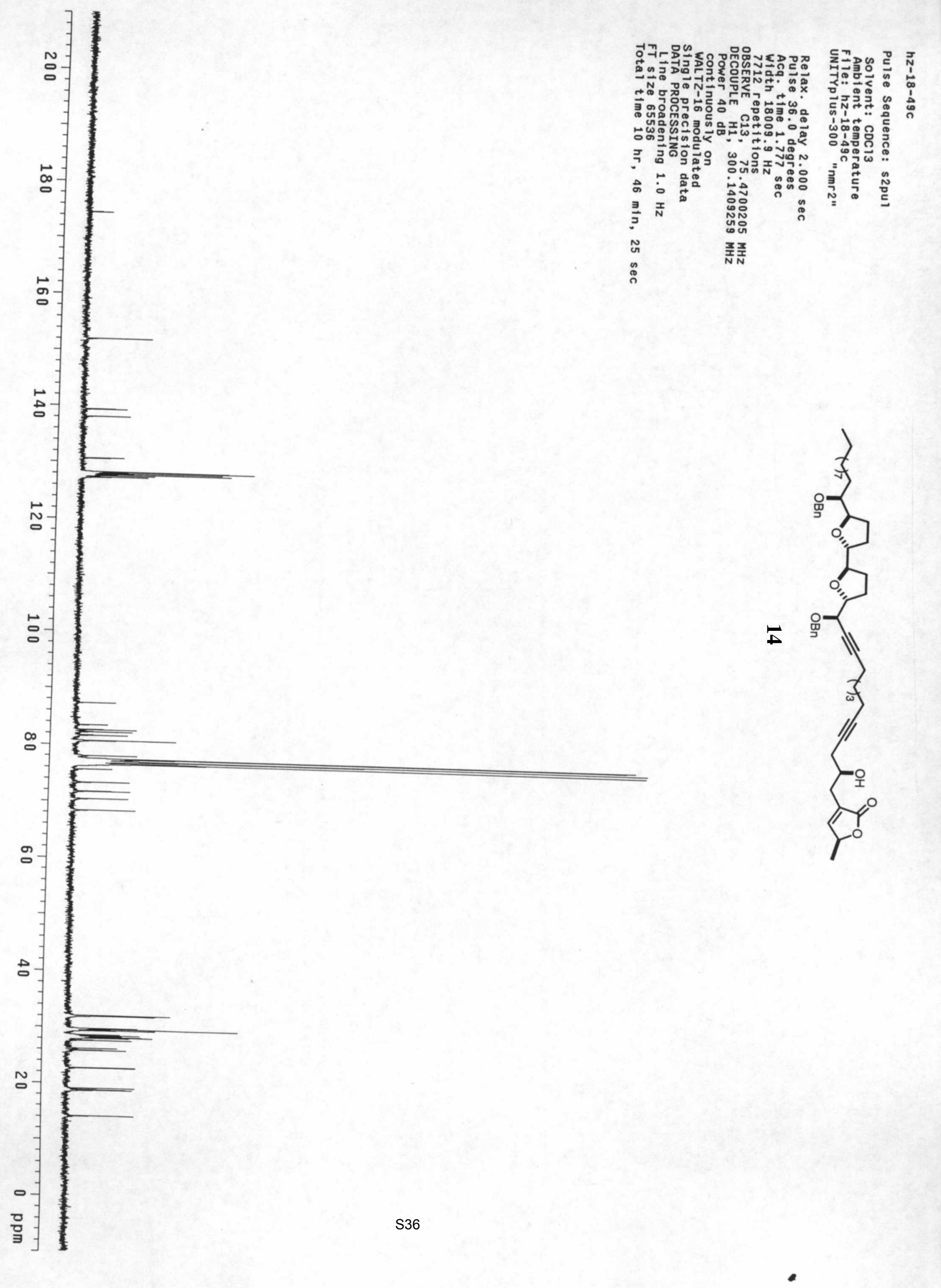




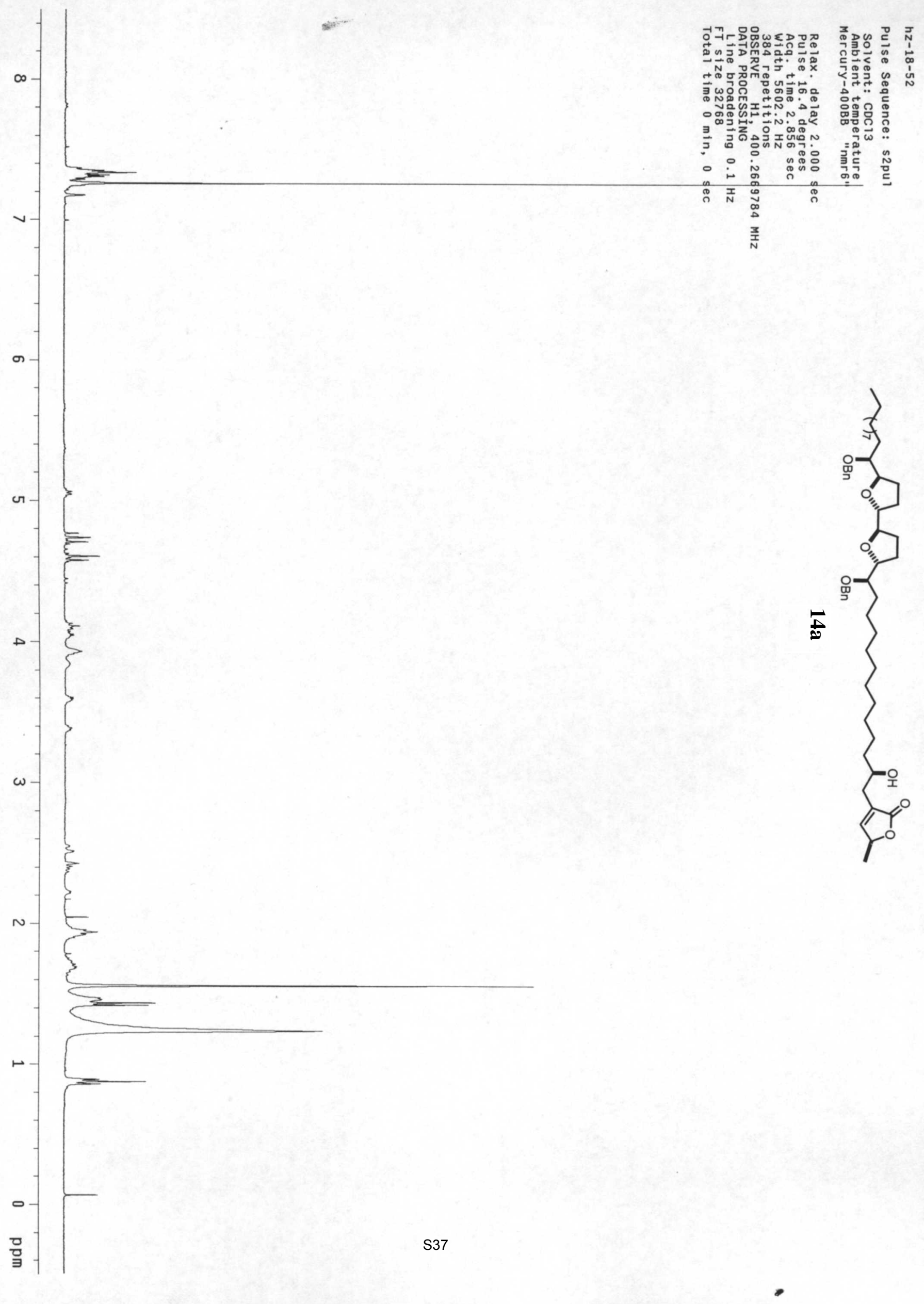




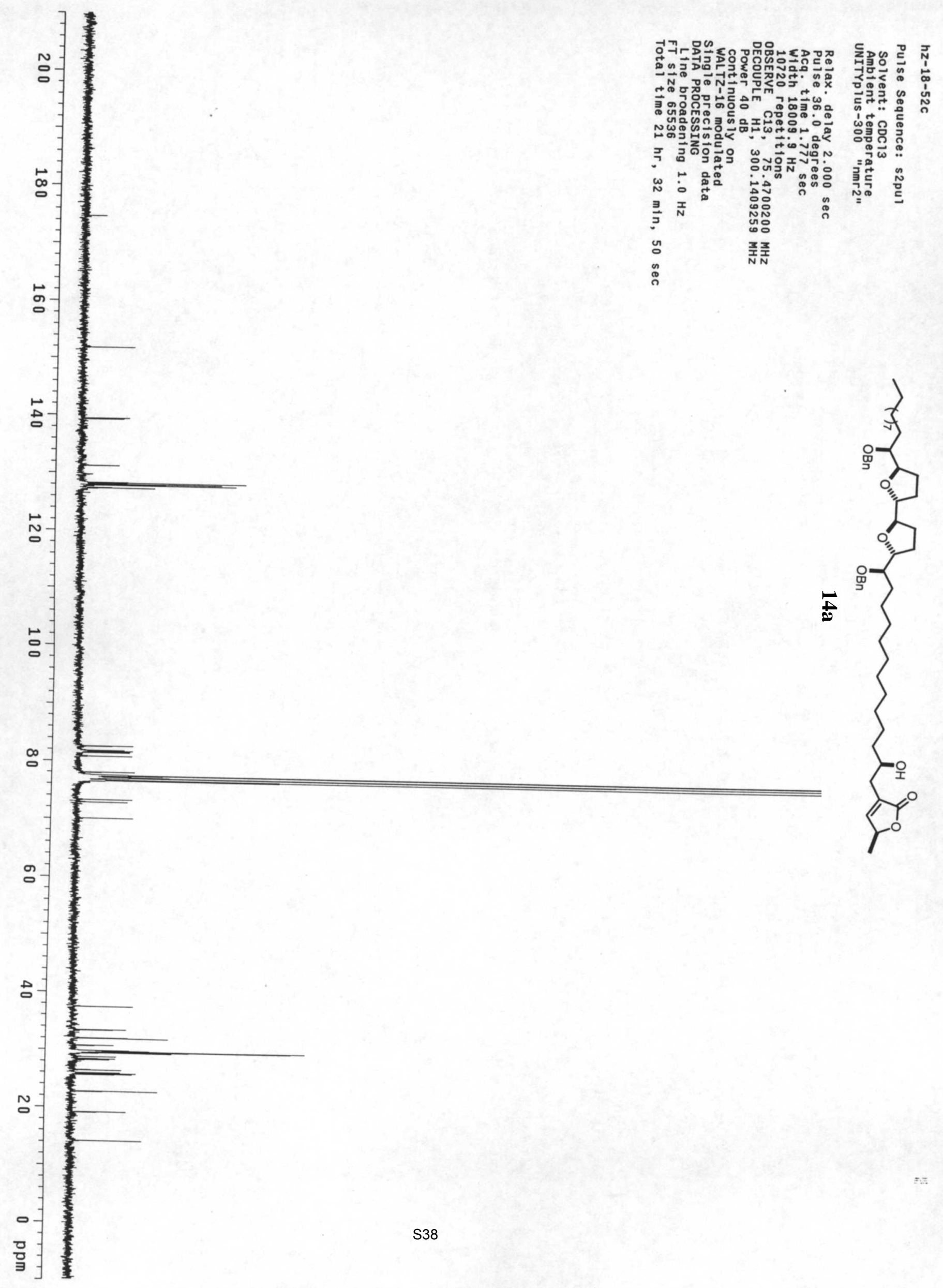




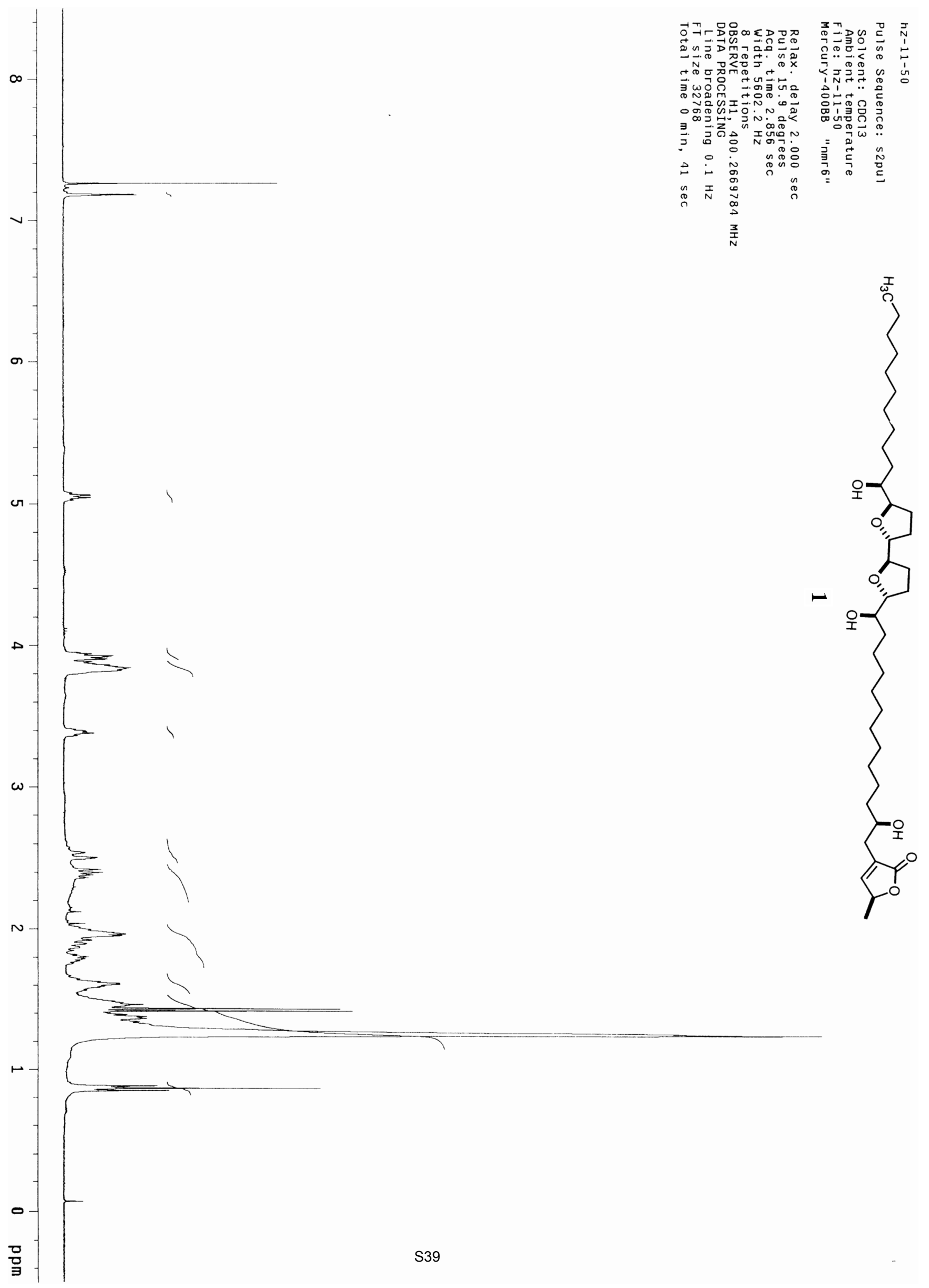




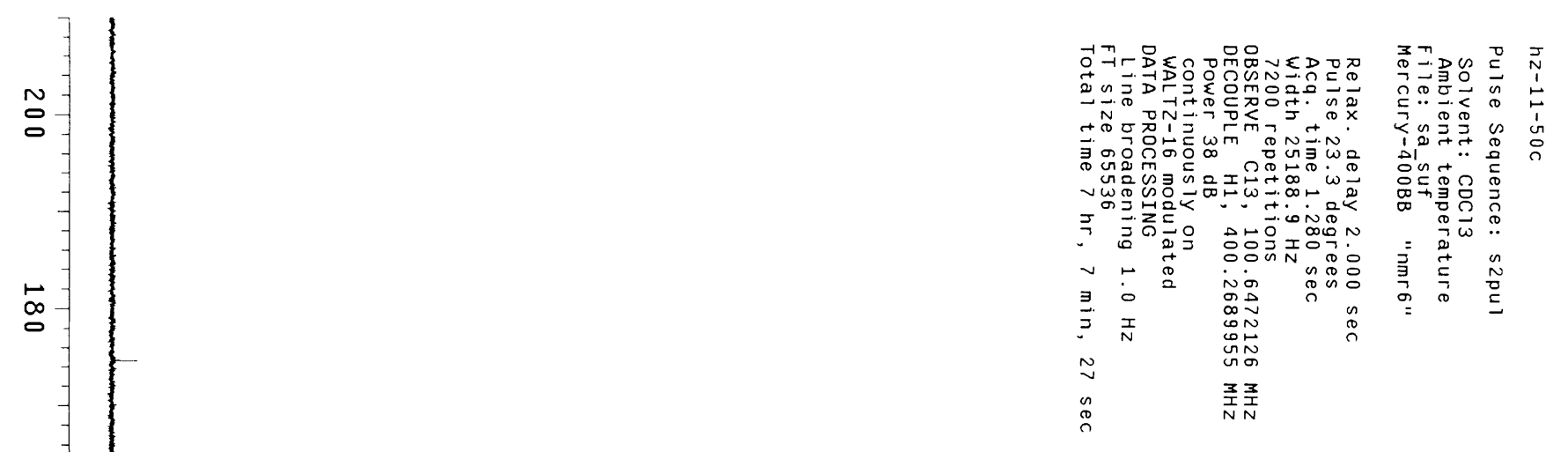

g

$\stackrel{\circ}{\circ}$

$\stackrel{\varpi}{\circ}$

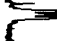
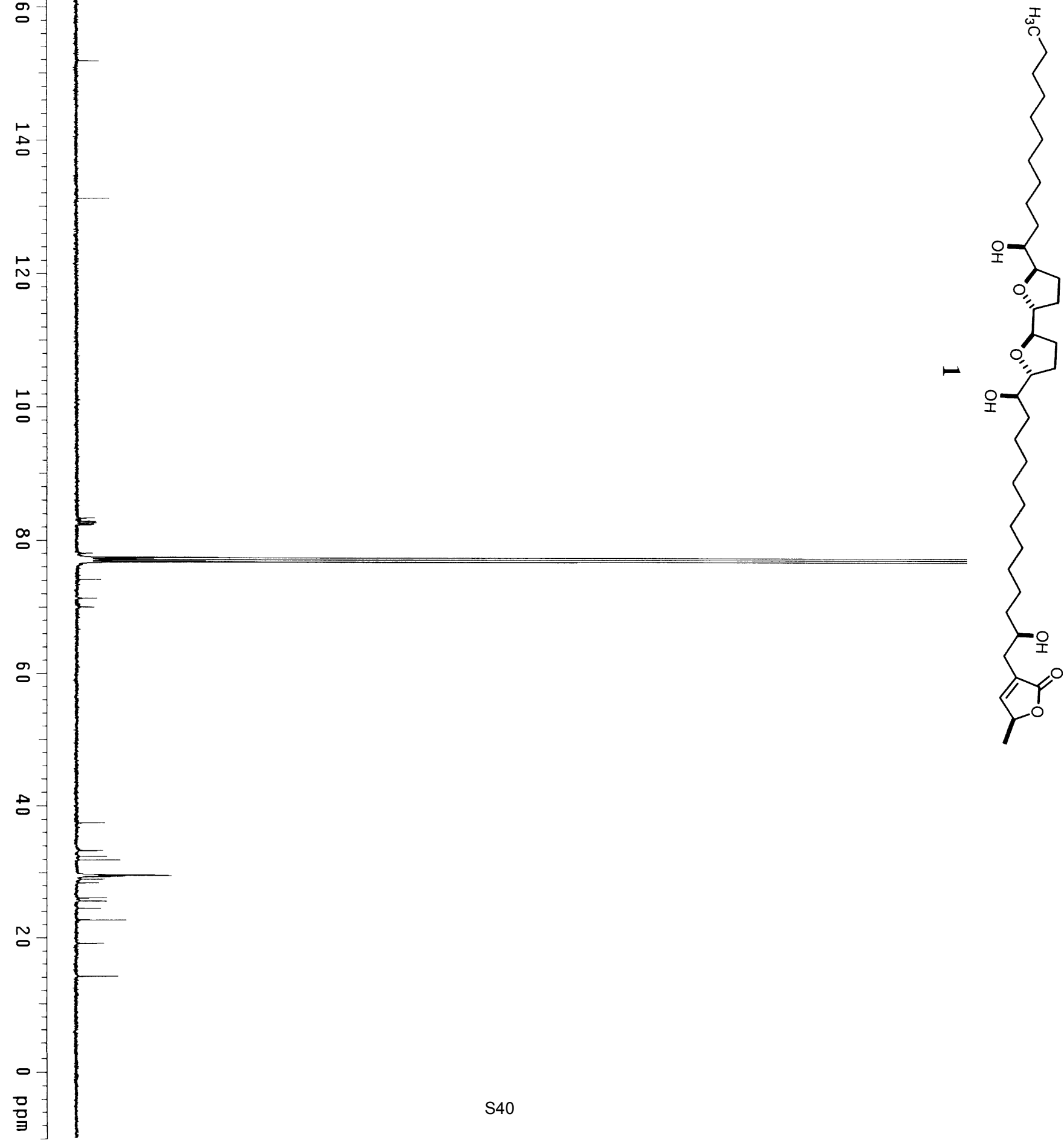


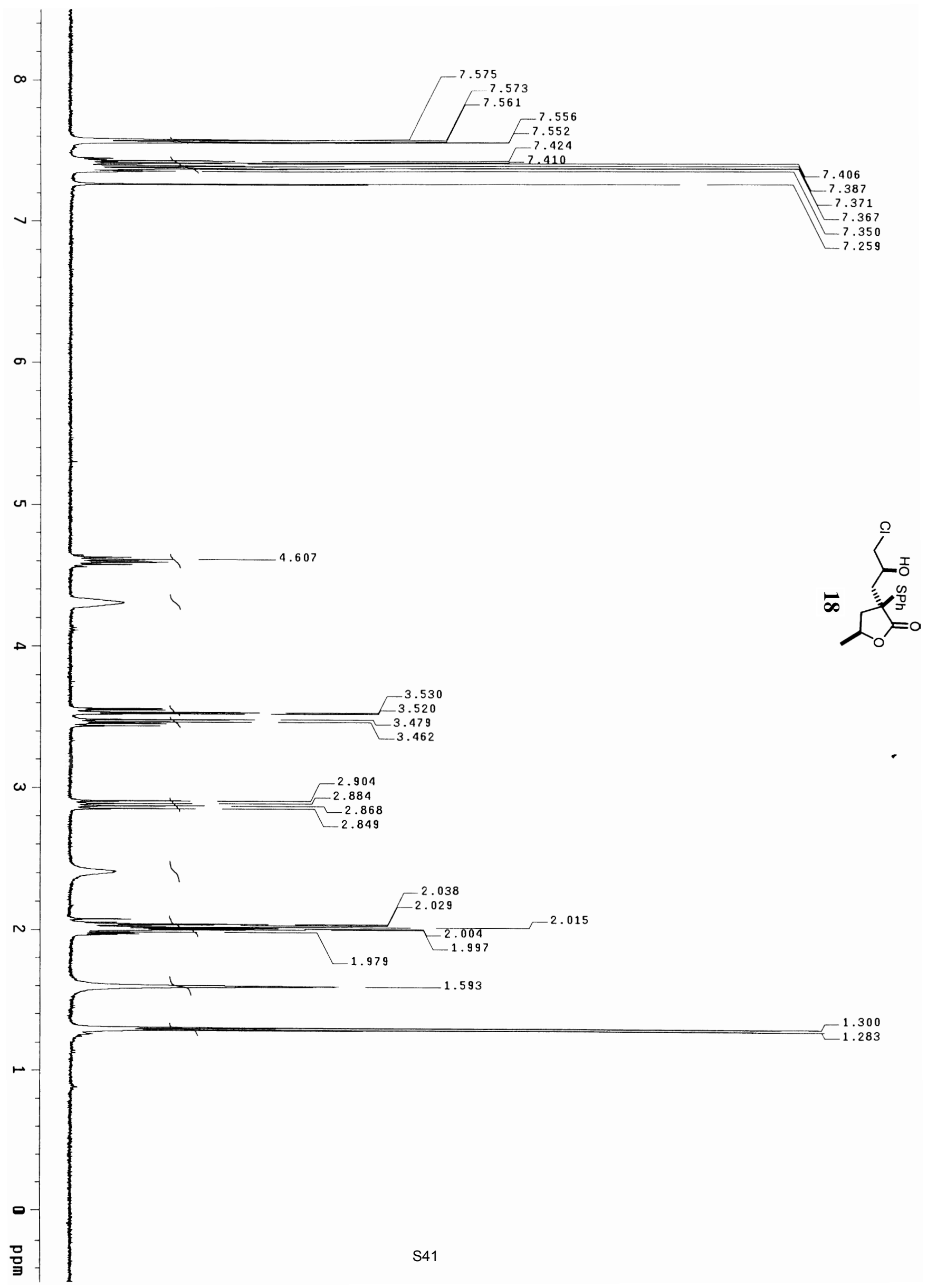




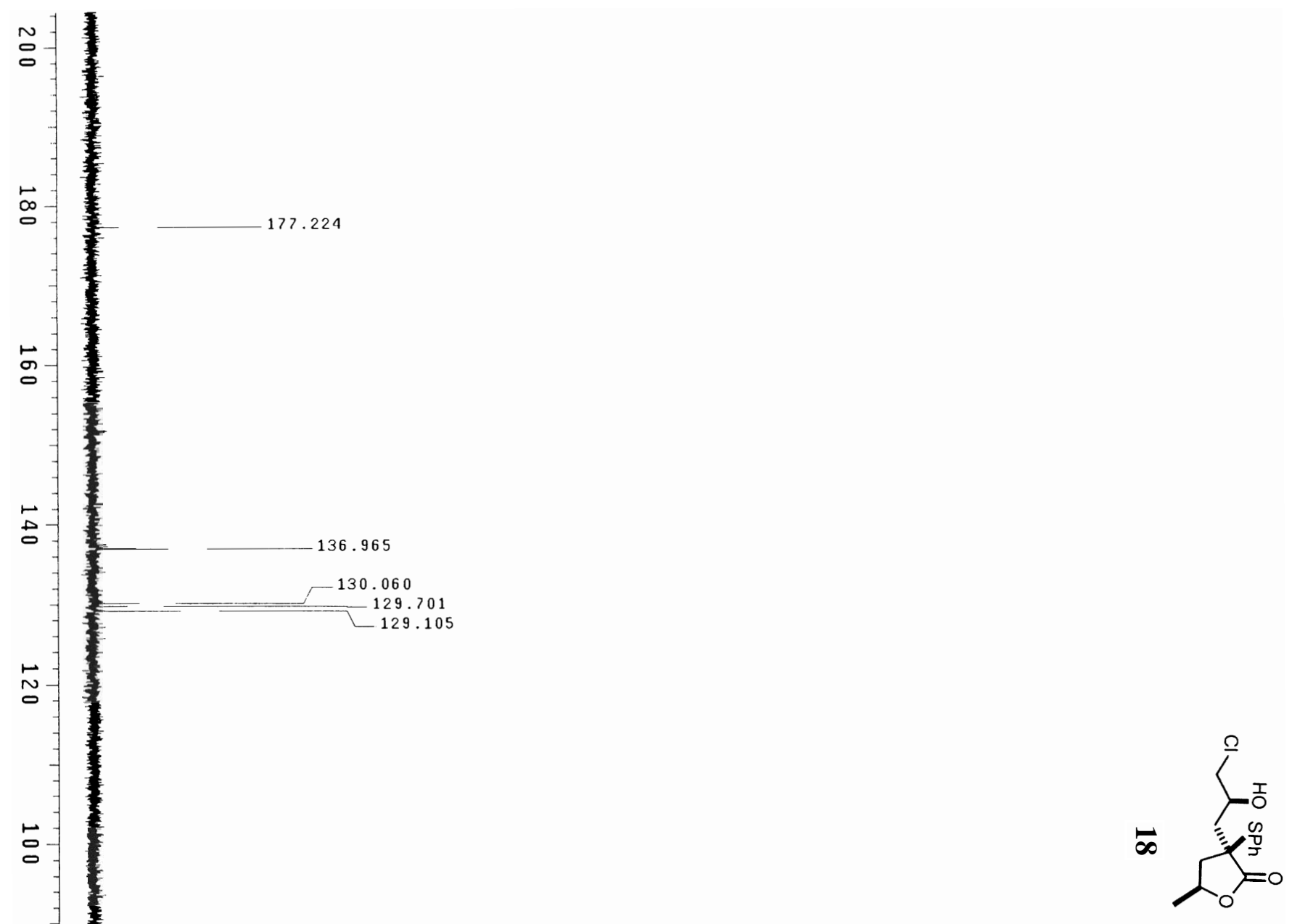

$\stackrel{\infty}{\circ}$
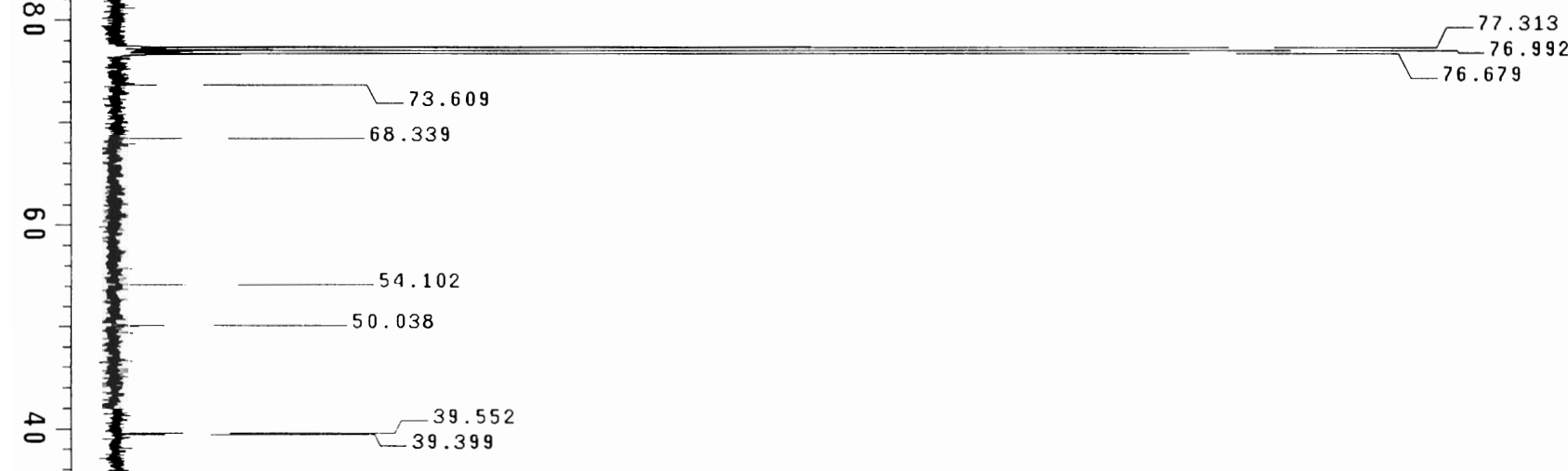

N- 21.366

읔-1 






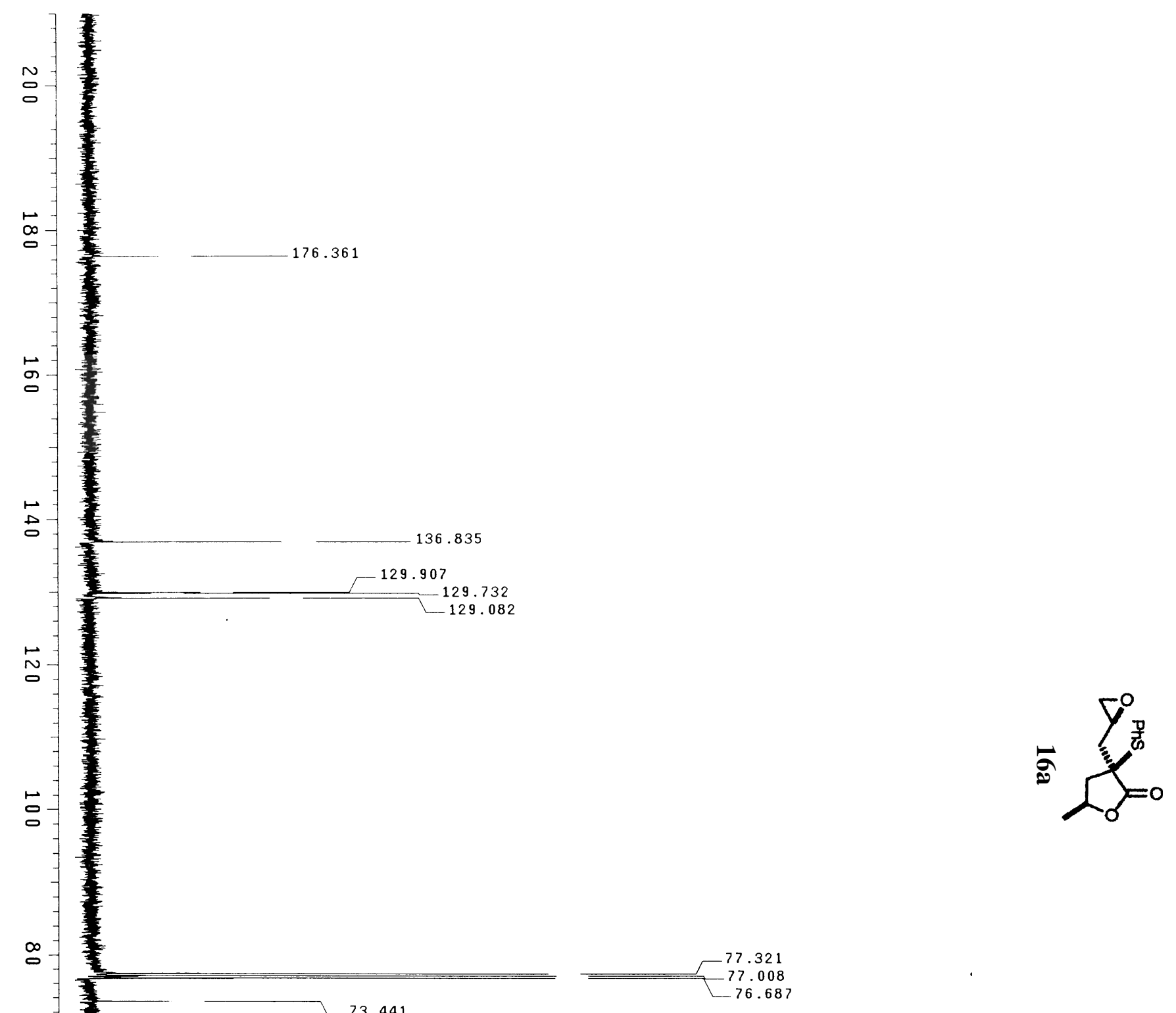

a

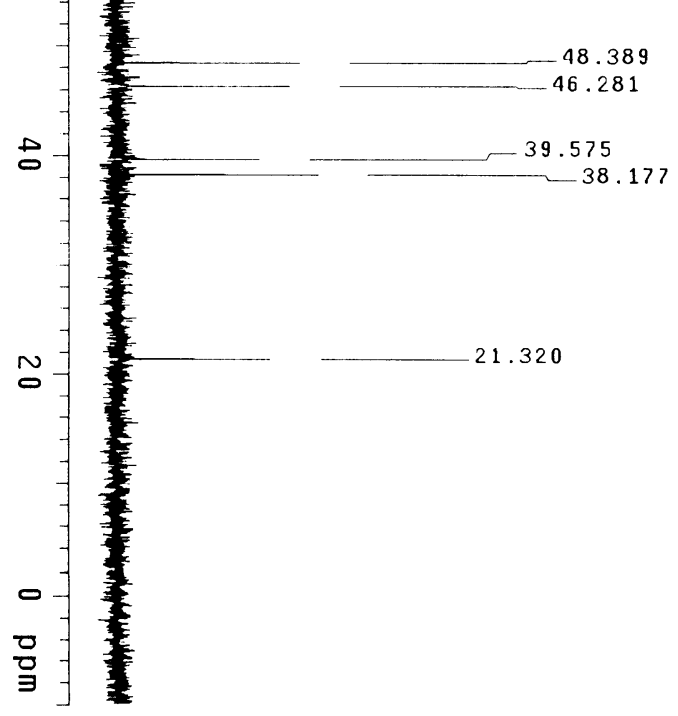




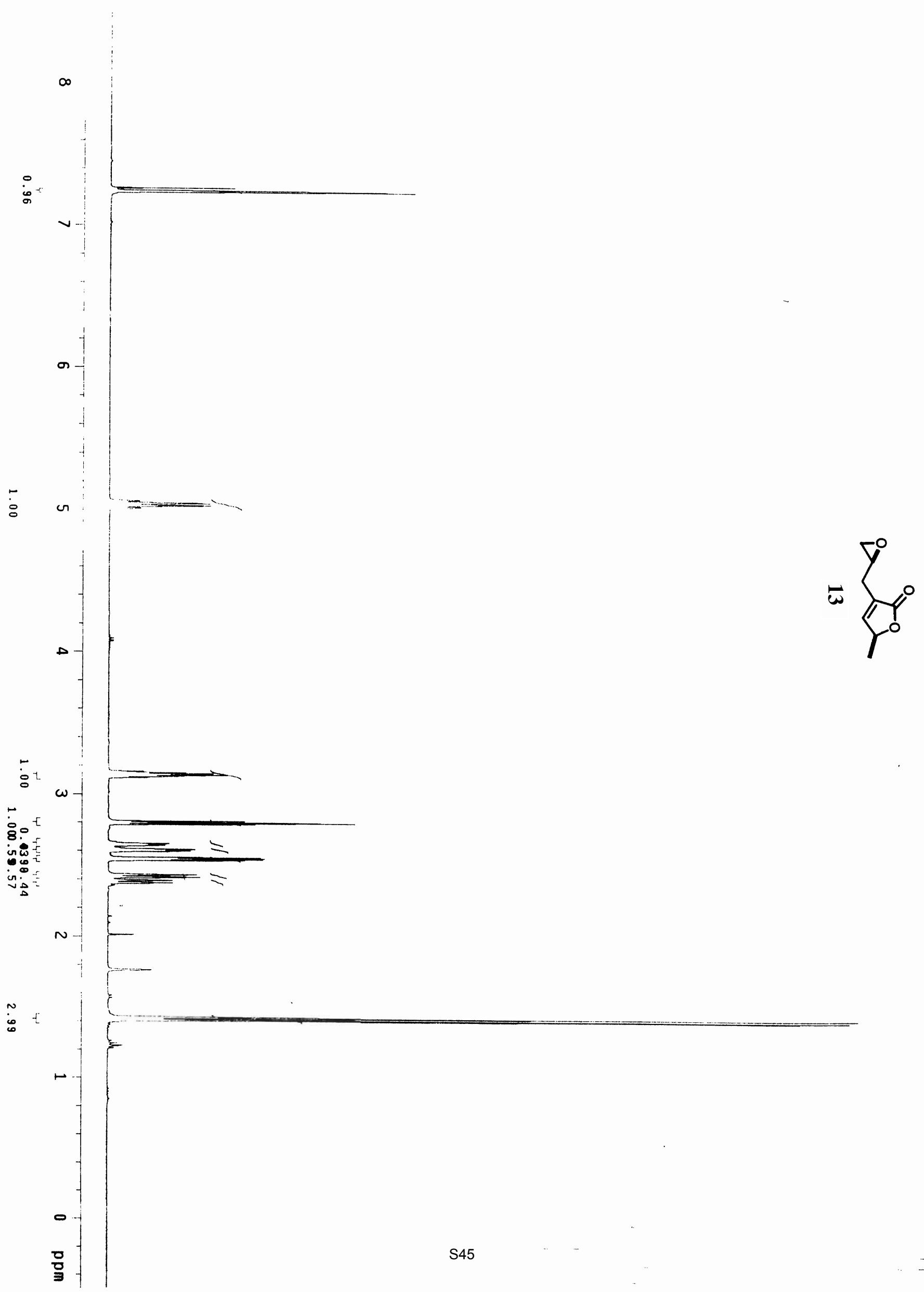



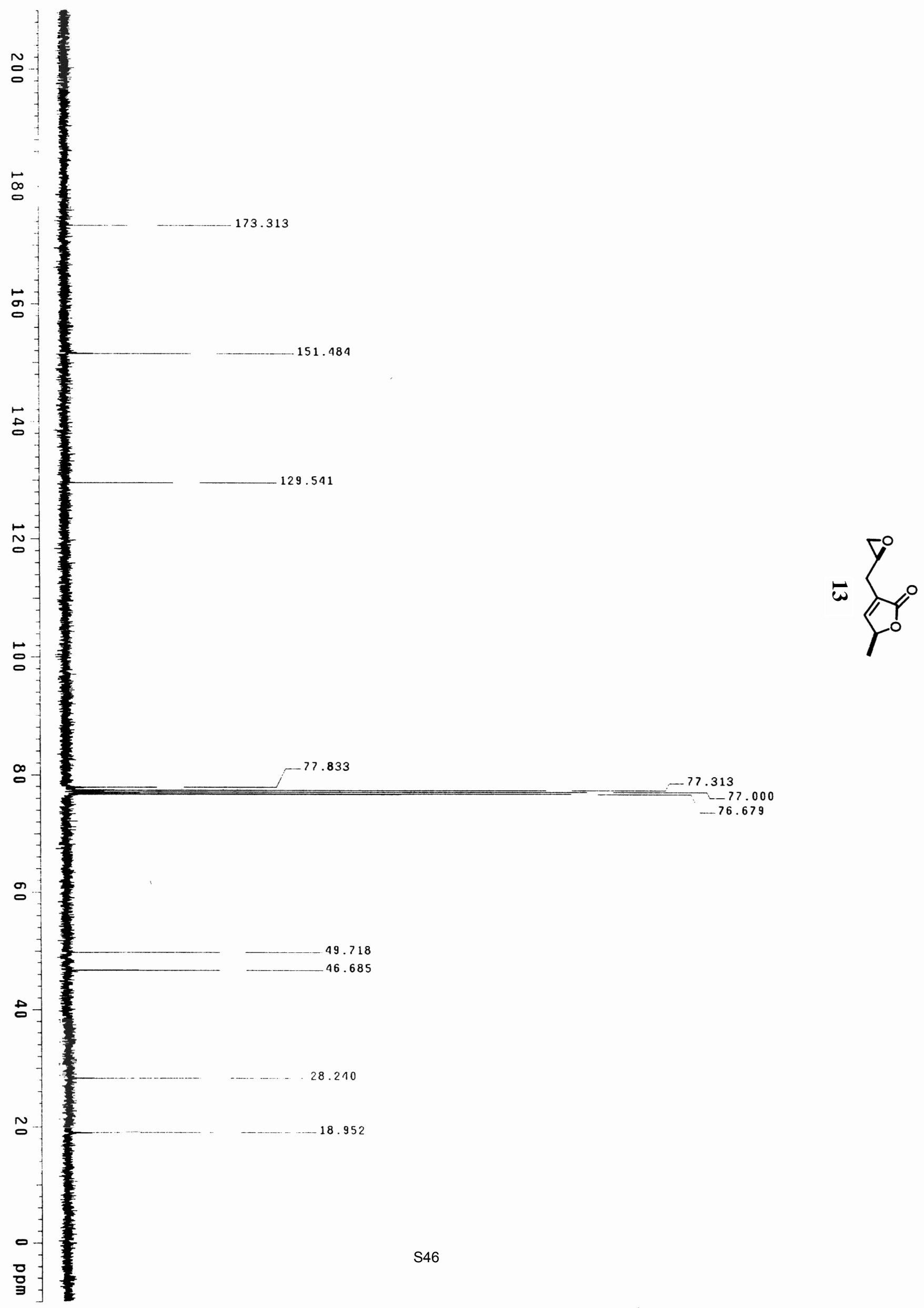